\title{
Land cover transitions and effects of transhumance on available forage biomass of rangelands in Benin
}

\author{
James Ellison ${ }^{1} \cdot$ Katja Brinkmann ${ }^{1,2} \cdot$ Rodrigue V. Cao Diogo $^{3} \cdot$ Andreas Buerkert $^{1}$ (D)
}

Received: 4 April 2020 / Accepted: 31 October 2021 / Published online: 30 November 2021

(C) The Author(s) 2021

\begin{abstract}
This study examined the effects of transhumance pressure on total abavoe-ground biomass and forage availability on rangelands in Benin. We also investigated the implications of land cover transitions on rangelands over a 31-year period. Our work was carried out in three regions of Benin representing distinct phytogeographic regimes: Ketou, Tchaourou, and Sinende. Ground-truthing and biomass sampling of the herbaceous and phanaerophyte strata were carried out between the 2016 peak vegetation period and the onset of the 2017 rainy season. Herbaceous biomass was determined by destructive sampling, and biomass of shrub and trees was estimated using non-destructive sampling and allometric equations. Historical and present-day Landsat data allowed an analysis of land cover change for the 1986-2002 and 2002-2017 periods. Land cover analyses yielded evidence of significant expansion of agricultural areas, especially in the latter period. The data also revealed progressive landscape fragmentation and transformations to a land cover of reduced total phytomass. There were no long-term effects of transhumance on trees, but likely on herbaceous biomass. Land cover changes in the study regions seem primarily the result of population pressure, infrastructural changes, persisting norms, and traditions regarding environmental management and the increasing popularity of livestock keeping as an insurance strategy. Rangeland transformations had negative impacts on transhumant herds' mobility and forage availability. As rangeland stability and consent between agricultural and pastoral land users are at a tipping point, informed policies, and land use planning that foster compromises among all stakeholders are needed.
\end{abstract}

Keywords Allometric equations · Biomass estimation · Land cover changes · Landsat · Transhumant pastoralism

\section{Introduction}

Transhumant pastoralism, a millennia-old practice in West Africa, is until today a dominant form of livestock production under seasonally strongly variable rainfall. Fulani are the most numerous and widespread group of pastoralists in West Africa, known for their

Andreas Buerkert

buerkert@uni-kassel.de

Extended author information available on the last page of the article 
long history of animal herding. These cross-boarder herders, an ethnic cross-border herders guide their mainly bovine herds through traditional herding corridors across the region (Hampshire, 2004; Bassett and Turner 2007). However, these traditional pastoral systems are under threat (Müller et al., 2007a) due to drastic changes in land use and land cover, an increased pressure on limited natural resources such as land and water, and (cross-border) conflicts among land users (Beyene, 2009; Gizachew, 2012). The Republic of Benin is a prime example in this context with significant annual cross-border migration of Fulani herders from Burkina Faso, Niger, and Nigeria. Although data specific to Benin seem unavailable, the FAO estimated in 2012 that more than 2 million cattle enter Benin, Nigeria, Chad, Mali, and Burkina-Faso annually.

The two major Sahelian droughts in 1973-74 and 1984 triggered the extension of migratory routes further south into the Guinean-Sudanian zone and more frequent visits to the sub-humid zone (Boutrais 2007; SWAC/OECD 2007; Ayantunde et al., 2014). Fulani originating from Niger and Nigeria have even resettled in new villages in northern Benin, partly destocking their herds, sometimes taking up farming (semi-transhumant agro-pastoralism; Diogo et al., 2017) and abandoning long-distance migration (agro-pastoralism) or taking up contract herding for the local community as a new source of livelihood (SWAC/ OECD 2007; Ayantunde et al., 2014). Nevertheless, the overall cattle stocking density in Benin is still on the rise (Fig. 1, FAO, 2018) and in recent times herd sizes in the southern and central parts of the country have surpassed those in the northern regions (Houessou et al., 2019), which leads to conflicts between land resource users.

To prevent recurrent cycles of violent conflicts between transhumant herders and farmers and to strategically manage the available rangeland resources, the parliament of Benin revised the national pastoral code in July 2018. The new regulation came into force in April 2019 (Code Pastoral Bénin, 2019) and defines new rules for transhumance in the country. Among others, a pastoralist is now allowed to herd up to 50 heads of cattle only during daytime, and night herding is prohibited. For cross-border transhumance, campaign periods are preset which run from December to May and from the northern part of the country to the central latitude of Dassa-Zoumè. However, national transhumance is still operational through predefined livestock passages and in specific phytogeographic areas of the country.
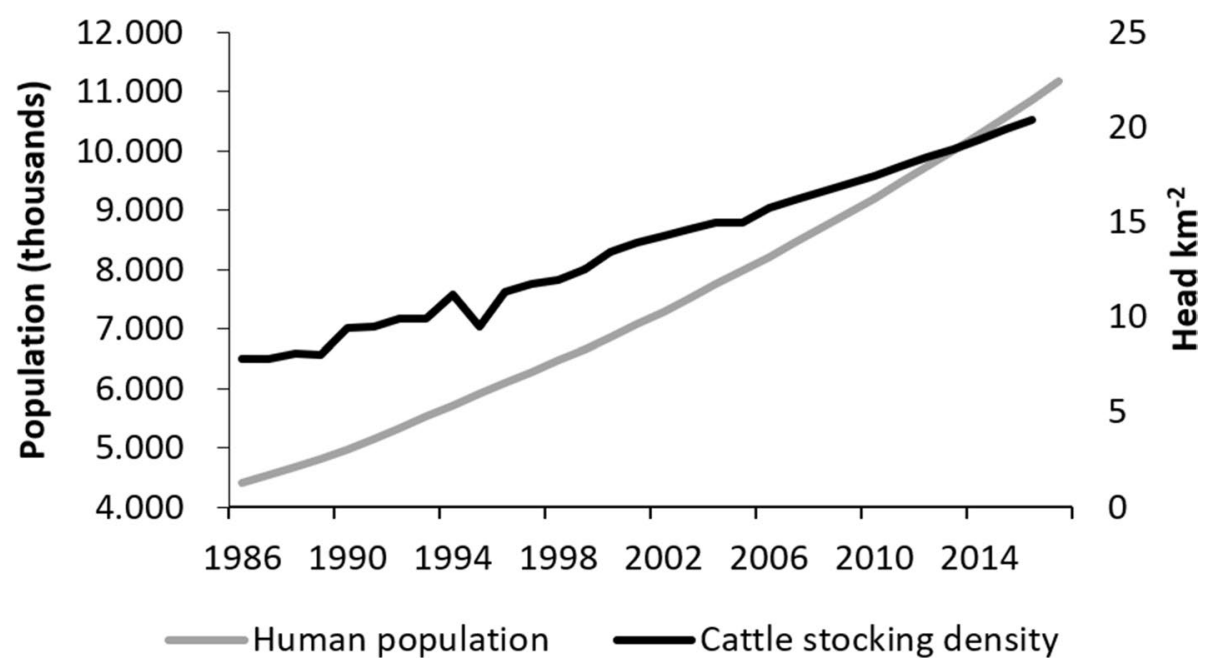

Fig. 1 Change in human population and cattle stocking density in Benin from 1986 to 2017 (FAO, 2018) 
For foreign transhumance, there are specifically set entry and exit points with predefined cattle numbers $(20,000-100,000)$ in each livestock host area. In case of infringement, sanctions may be implemented (Decret Ministériel, 2019).

Aside from the contribution of climatic factors, these changes in management and land use of agro-pastoralists over the last four decades were probably also a response to significant land use and land cover changes (LULCC) such as agricultural expansion and deforestation affecting availability of rangeland resources (Houessou et al., 2019). Like elsewhere in West Africa, LULCC were mainly triggered by rapid population growth $(0.66 \%$ per annum in Benin since 1986; FAO, 2018) and urbanization (Brinkmann et al., 2012; Guidigan et al., 2018; Lambin et al., 2003). However, the underlying causalities of LULCC are more complex and still poorly understood due to the interplay of various socio-economic, biophysical, technological, institutional, and cultural factors at different scales (Lambin et al., 2001).

LULCC affect forage provision and feed resource composition, and they may also result in feed deficits and changes in feeding management strategies since traditional feed resources are no longer adequate to sustain a productive livestock population (Benin et al., 2002; Sarwar et al., 2002). Despite being an important source of forage during the dry season (Schlecht et al., 2006), cropland and its expansion takes its toll on forage availability because these land units become off-limits to herds and herders during the cultivation period (Diogo et al., 2021). This reduces the size of the transhumant corridors and together with landscape fragmentation that further limits the mobility of livestock has a negative impact on herds' access to spatially heterogeneous vegetation resources (Hobbs et al., 2008). Since access to heterogeneous vegetation and carrying capacity of the land are positively correlated (Hobbs et al., 2008; Wang et al., 2006), it can be deduced that rangeland transformations that limit livestock mobility to certain land units will constrain productivity unless herd sizes are reduced.

Despite a substantial literature body on grazing effects on vegetation composition in West Africa, the interactions of transhumant pastoralism mobility, LULCC, and availability of feed resources are still poorly understood. Such understanding is, however, needed to derive effective policies fostering herders' livelihoods and rangeland sustainability. In this study, we therefore combine a remote-sensing-based analysis of the land cover evolution with an investigation of the differences in annual and perennial phytomass between rangeland areas with a strong and a weak pressure of (cross-border) transhumant herds. We hypothesize that a long-term tendency of land cover transitions favours land cover with less total phytomass and less available forage.

Our second hypothesis is that the levels of phytomass do not significantly differ between zones grazed by transhumant herds and other comparable rangelands. This is of sociopolitical relevance in Benin where transhumant herders who currently undergo a rapid socio-technological transformation (Djohy, 2017) are often blamed for apparent degradation of rangelands (Butt, 2010; Rowntree et al., 2004; Smith, 2006).

\section{Materials and methods}

\subsection{Description of the study regions}

Transhumance in Benin is mainly characterized by the north-south movement during the dry season (January-May) over distances $>100 \mathrm{~km}$ ). On their way back from the northern 
summer pastures, herds spend a few days at Angaradebu in north Benin (municipality of Kandi) and then move down to the country's centre, the municipality of Tchaourou, and finally to the southern municipalities around Ketou (Lesse et al., 2015). Interestingly, these movements down to the southern and coastal regions are driven not only by the search for high-quality forage and water, but also by the availability of reliable markets to sell animals and the desire to cross with breeds from the south to improve the animals' meat and milk performance (FAO, 2012). This north-south movement is often called cross-border transhumance, whereas an inverse transhumance with a south-north movement takes place at the onset of the rainy season until the start of the dry season (June-December; Abbagana and Youla 2009).

Along the cross-border transhumant corridor in Benin (Lesse et al., 2015), we selected three different concentration and destination zones characterized by different agro-climatic conditions and named them according to the commune in which they are located: refers to as one of the destination areas in the south and the concentration zones along the transhumance route, Tchaourou in the centre and Sinende in the north (Table 1). All regions, in particular Ketou and Tchaourou, are characterized by a comparatively high availability of fodder and water resources, which makes them attractive as destinations for transhumant herds.

Croplands at the three study sites are characterized by a mosaic of trees within fields with cereals (maize, Zea mays L.; sorghum, Sorghum bicolor (L.) Moench.), legumes (bean, Phaseolus spp.; cowpea, Vigna unguiculata Walp.), and root crops (cassava, Manihot esculenta Crantz.; yam, Dioscorea spp.). Due to its relative proximity to the capital, Ketou is well-connected to the south (and thus to agricultural investments). While the Peulh ethnic group practices transhumance throughout the country, Sinende has been settled by a large sedentary population of Peulh, partly triggered by the droughts in the 1970s and 80 s that induced transhumant pastoralists from Niger and Nigeria to permanently settle in northern Benin (SWAC/OECD 2007). The estimated livestock densities (LUs km²) differ between study sites with a significantly higher cattle density reported for Sinende in the north (Table 1). Similar to population trends, the cattle stocking density in Benin is still rising (Fig. 1).

\subsubsection{Delineation of transhumance zones}

To explore the possible effects of transhumance on annual and perennial phytomass, it was necessary to distinguish between zones used by transhumant herds versus zones mostly restricted to grazing by local herds. However, the grazing areas of transhumant herds within the cross-border transhumance corridor often do not follow specific routes and rules and are very dynamic in space and time. Due to the difficulties of their spatial allocation, we simply delineated encampment areas with a strong pressure of transhumance (ST zones) for selected village communities in each study region (Fo-Bourre, Sakarou, and Peulh camp in Sinende; Adjimon, Sanson, Gokana, and Yerimarou in Tchaourou; Adakplame, Ewe, and Ofia in Ketou). These transhumant hot spots were compared with the surrounding community rangelands (within a $4 \mathrm{~km}$ buffer around ST zones), which are also called weak transhumance (WT) zones. For this, we used existing government data coupled with community knowledge through surveys (AOC, 2006 for Sinende; Chabi Boom 2011 for Tchaourou); and community knowledge of transhumant corridors only for Ketou. 


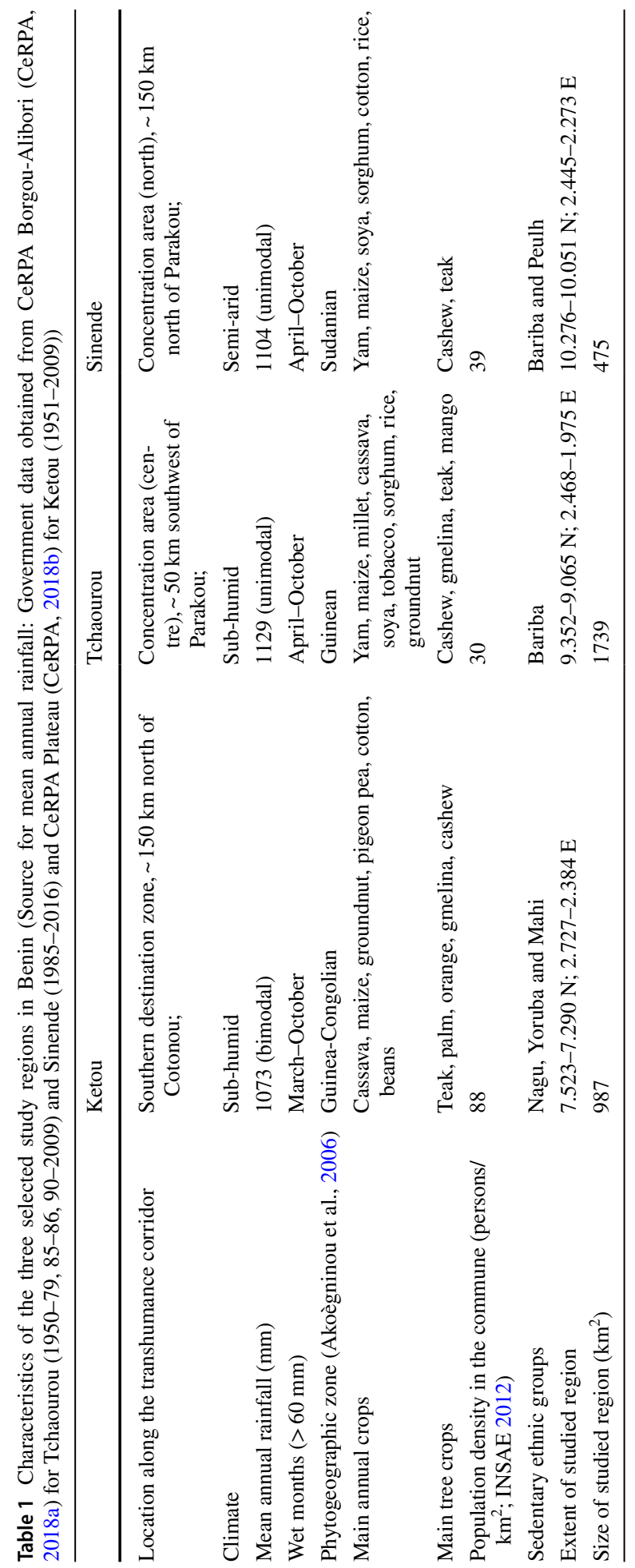


(c)

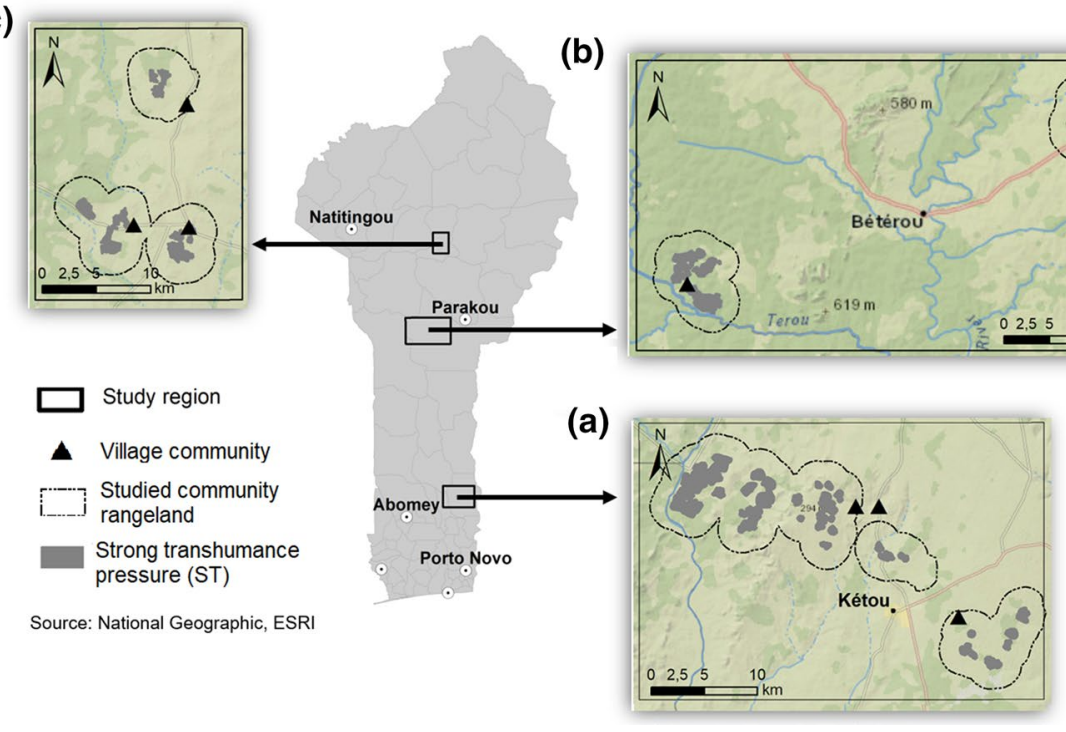

Fig. 2 Location of the three selected study regions a Ketou, b Tchaourou, and $\mathbf{c}$ Sinende and studied community rangeland within the study regions in Benin

Table 2 Satellite sensor, date of acquisition, and spectral and spatial (m) resolution of the Landsat satellite dataset used for supervised classification in the three study regions of Benin

\begin{tabular}{lllllll}
\hline Year & Satellite (sensor) & Resolution $(\mathrm{m})$ & \multicolumn{2}{l}{ Date of acquisition } & \multirow{2}{*}{ Bands used } \\
\cline { 3 - 5 } & & & Ketou & Tchaourou & Sinende & \\
\hline 1986 & Landsat 5 (TM) & 30 & 31.12 .1986 & 02.03 .1986 & 02.03 .1986 & $1,2,3,4,5,7$ \\
2002 & Landsat 7 (ETM+) & 30 & 17.01 .2002 & 02.02 .2002 & 02.02 .2002 & $1,2,3,4,5,7$ \\
2017 & Landsat 8 (OLI) & 30 & 18.01 .2017 & 23.03 .2017 & 23.03 .2017 & $2,3,4,5,6,7$ \\
\hline
\end{tabular}

The delineated known ST zones amounted to a total of 1918 ha at Ketou, 1579 ha at Tchaourou, and 882 ha at Sinende, respectively (Fig. 2).

The size of the area used to explore land cover changes was based on the extent of the ST zones within study regions by using a 4-km buffer around the outer extents of ST zones. The resulting limits were regarded as the boundaries of the study region.

\subsection{Land cover classification and accuracy assessment}

We used satellite imagery captured by the Thematic Mapper (TM), Enhanced Thematic Mapper Plus (ETM+), and Operational Land Imager (OLI) sensors aboard the Landsat 5, 7 , and 8 satellites with a resolution of $30 \mathrm{~m}$ (Table 2). Landsat high-level surface reflectance (SR) products, which underwent solar and atmospheric corrections, were acquired through the US Geological Survey's Earth Resources Observation and Science (EROS) service. 
Due to the high cloud coverage $(>10 \%)$ of rainy season images, only images from the mid- to late dry season were used for classification. The December 1986 image acquired for Ketou (chosen due to the lack of quality images prior to the wet season) was taken after the 1986 wet season (Table 2) and thus, reflects land cover during the 1986-87 dry season (about 9 months later than at the other sites).

Supervised classifications were performed using the Semi-Automatic Classification Plugin (SCP) (version 5.3.8; Congedo, 2016) within QGIS (version 2.18.10, QGIS Development Team, 2018). To define the initial land cover classes and collect training data for subsequent land cover classification, extensive ground truth data were gathered along transects depicting a large variety of land cover types, which have been selected using Google Earth $^{\circledR}$ images from 2016 and 2017 (Table 3).

At each site, 150 to 200 pre-defined ground-truthing GPS points were visited for the identification of the land cover in the field and collection of training data. Because fire was a dominating landscape factor at all sites, signs of past burning in the field were recorded at each GPS point at the end of the dry season using the following classification: (1) very recent fire, (2) recent fire, (3) signs of an old fire, and (4) no signs of fire. Very recent fires were defined by the presence of white ash, which is quickly dispersed after a fire by rain and wind, while older fire sites were defined by charred wood at the base of tree trunks and charred residues on top of the soil.

In addition, different band combinations of Landsat 8 images were used for the selection of training areas: a colour infrared composite for the detection of healthy vegetation (band 5,4,3), a false colour composite to identify urban areas (band 5-4-3) and a "fire" composite (band 7-5-2) enabling the division of burned areas. Only areas in which both the colour infrared Landsat images and high-resolution $(\leq 15 \mathrm{~m})$ Google Earth imagery indicated the same land cover were accepted as training areas. These areas were created using SCP's region-growing algorithm (Congedo, 2016), which excludes "stray" pixels that do not fall into a given pixel similarity (distance in surface reflectance units).

Table 3 Land cover categories used for supervised classification in the three study regions of Benin

\begin{tabular}{ll}
\hline Class name & Characterization on the ground \\
\hline $\begin{array}{l}\text { Dense forest } \\
\text { Plantation }\end{array}$ & $\begin{array}{l}\text { Dense, closed canopy forests or forest fragments or high-canopy riparian forest } \\
\text { Confined, densely populated areas of species of the Anacardiaceae family (mango } \\
\text { and cashew) }\end{array}$ \\
$\begin{array}{l}\text { Open forest/ } \\
\text { Wooded savannah }\end{array}$ & $\begin{array}{l}\text { Sparse, open canopy forested areas or tree-dominated savannahs } \\
\text { Shrub savannah }\end{array}$ \\
$\begin{array}{l}\text { Land where shrubs are more common than trees, and herbaceous plants prevail } \\
\text { between the shrubs (shrub dominated savannah) }\end{array}$ \\
$\begin{array}{l}\text { Land dominated by non-woody plants from an aerial perspective (grass dominated } \\
\text { savannah) } \\
\text { Dense shrubland } \\
\text { Cropland }\end{array}$ \\
$\begin{array}{l}\text { A stand of shrubs with a closed canopy } \\
\text { been removed }\end{array}$ \\
$\begin{array}{l}\text { Built-up } \\
\text { Rock outcrop }\end{array}$ & $\begin{array}{l}\text { Small rocky outcrops or larger inselbergs, especially where the vegetation has been } \\
\text { removed }\end{array}$ \\
Open water, especially rivers, wetlands and dammed impoundments
\end{tabular}


Using a two-step classification approach, we ensured that the spectral range between any two training classes did not overlap on at least one of the six bands. In the first step, pixels whose signatures were completely contained within the spectral range for a certain class were assigned to that class. Spectral range thresholds were maintained at the minimum and maximum values for each defined class. Next, pixels that fell in overlapping regions or outside of any of the spectral ranges were classified according to the "minimum distance" algorithm. The minimum distance algorithm calculates the Euclidian distance between the spectral signatures of pixels and training spectral signatures and assigns the pixel to the class to which it is closest.

Approximately half of the ground-truthing points were used to perform an accuracy assessment. This was supplemented by additional validation points using stratified random sampling to ensure that all classes were well-represented with regard to their proportion of the total area. From the error matrices, the quantity disagreement, allocation disagreement (Pontius \& Millones, 2011), and overall accuracy were calculated.

For the historical land cover classification, there were no ground-truthing data available with which training areas could be verified and map accuracy could be validated. For the 2002 classifications, each of the 2017 training areas was compared with 2002 images (natural and false colour composites) to verify its applicability. Due to rapid land cover change over the 15-16 year time lapses, a majority of 2017 training areas could not be used to classify the 2002 image. These were instead replaced with training areas identified through the composite images whose spectral signatures fitted into the spectral range for that class. Signatures were re-calculated using 2002 reflectances. The same procedure was performed in ascertaining the validity of 2002 training areas for the classification of 1986 images.

\subsection{Biomass sampling and analysis}

\subsubsection{Stratified random sampling design}

To collect biomass samples in ST and WT zones of the study regions, we employed a stratified random sampling design based on an existing land cover map of Benin (CENATEL-USGS-CILSS, 2013). We restricted biomass sampling to the most important land cover classes occurring in the three study regions, namely wooded savannah, shrub savannah, and cropland. For each study region and zone, biomass samples were randomly distributed within the three land cover class areas according to the total extent of each land cover class resulting in 3-15 samples for wooded savannah, shrub savannah, and cropland.

At each sampling point, a $900 \mathrm{~m}^{2}$ plot $(30 \times 30 \mathrm{~m})$ was established representing a relatively homogenous area in terms of land cover and vegetation type; burned areas were avoided. Within the plot, five $1 \mathrm{~m}^{2}$ subplots were systematically established at the four corners and at the centre of the $900 \mathrm{~m}^{2}$ plot. Trees and shrubs were measured on the whole plot and herbaceous plants only on subplots (see below).

\subsubsection{Destructive sampling of grass and forb biomass}

Herbaceous biomass sampling was performed during peak vegetation growth at Tchaourou. However, due to the impossibility of sampling in the three study regions 
simultaneously, sampling was performed just after peak vegetation at Sinende and afterwards at Ketou (Appendix A). For the destructive biomass measurement of herbaceous plants, all grasses and forbs within the $1 \mathrm{~m}^{2}$ subplots were cut at a height of $1 \mathrm{~cm}$ above the soil surface, and their fresh weight was measured. Dry matter weight was determined by taking subsamples of the grass and forbs collected from the subplots. These were air-dried and again oven-dried $\left(65^{\circ} \mathrm{C}\right)$ to constant weight.

Herbaceous crop residues are an important fodder source in terms of quality but have a limited temporal availability. In many cases, residues are consumed by animals or are otherwise removed from crop fields in the weeks following harvest. For this reason, they were not measured in this study.

\subsubsection{Phanerophyte biomass sampling and allometric equations}

The estimation of tree and shrub biomass was only performed for the most dominant phanerophytes, which were identified based on an already existing vegetation survey for the three study regions (Diogo, 2018). For this, the frequency of each species was summed up for each study region and the relative abundance of each species was calculated. We defined dominant phanerophytes as species with a relative abundance greater than $1.5 \%$ comprising approximately $80 \%$ of all phanerophytes at Ketou, and $72 \%$ each at Tchaourou and Sinende, respectively.

During sampling, which occurred during the dry season at all sites, the prescribed measurements were based on the growth form of the phanerophyte specimen. Dominant phanerophyte species were categorized through observation as taking on either a tree or shrub growth form, and the corresponding sampling methodology was then used for their measurement. Most of the phanerophyte species retained a major part of their foliage during the dry season.

For the 19 dominant tree species for which allometric equations were available from literature (Appendix B), we measured the diameter at breast height (DBH) of all individuals with a $\mathrm{DBH}>10 \mathrm{~cm}$ within the $900 \mathrm{~m}^{2}$ sample plot. For mango (Mangifera indica), the crown diameter was also determined. All non-dominant specimens with a $\mathrm{DBH}>30 \mathrm{~cm}$ were additionally measured due to their significant contribution to total biomass. We also recorded crown diameter and total height of all shrubs within the 900 $\mathrm{m}^{2}$ plot.

2.3.3.1 Allometric equations to estimate tree biomass: Although some minor differences existed between allometric equations from different sources, generally equations accounted for the above-ground biomass in the stem with the bark, and large and small branches $>3 \mathrm{~cm}$ DBH. Equations from Beninese studies were preferred, although studies from other parts of Africa were seen as the next best option over studies from other parts of the world. Except for four equations which related DBH directly to biomass, all other equations yielded tree total above-ground volume. The product of tree total volume and wood density (which was also acquired from various literature sources) thus yielded tree total above-ground biomass.

2.3.3.2 Allometric equations to estimate shrub biomass: Due to lacking allometric equations for shrubs species, it was necessary to measure dry matter of eight shrub species to establish equations for biomass estimation. Sampling focused on twig and 
leaf biomass, as these are the plant parts that have forage value for livestock. In each study region, we sampled for the dominant species three individuals per height class $(1=1-2 \mathrm{~m}, 2=2-4 \mathrm{~m}$, and $3=4-6 \mathrm{~m})$. For shrub species which were too large to allow complete harvesting of twigs and leaves, a subsample of branches was harvested, and quantities were extrapolated based on the number of non-harvested branches. Only individuals of good vitality were chosen for destructive sampling. This ensured that effects like those from dry season leaf shedding (which is minimal for many trees and shrubs) and fire exposure were minimized. For each harvest, viable leaf and twig parts $(>3 \mathrm{~mm})$ were separated and weighed fresh in the field. A subsample of each component was then taken, air-dried, and later oven-dried at $65^{\circ} \mathrm{C}$ to constant weight.

For the establishment of allometric equations for shrub species, a dataset of 91 sampled (harvested) shrub specimens was used. Shrub crown area and volume were calculated, assuming elliptical and elliptical prism crown models, respectively. These parameters were then plotted against leaf and twig dry matter (Appendix C). Various regression types (linear, exponential, power, and logarithmic) were compared in order to identify the best-fitting allometric equations for the prediction of leaf and twig dry matter. Power functions best predicted the relationship between crown area/volume and leaf and twig biomass (Appendix C). Given the higher coefficient of determination for the crown volume model $\left(r^{2}=0.70\right)$ in relation to the crown area model $\left(r^{2}=0.65\right)$, species-specific equations were developed to predict leaf and twig dry matter from crown volume. The species-specific Eqs. $\left(0.64 \leq \mathrm{r}^{2} \leq 0.99\right)$ were used to derive leaf and twig dry matter for 1,151 individual shrub specimens of the following species: Annona senegalensis, Flueggia virosa, Gymnosporia senegalensis, Piliostigma thonningii, Pteleopsis suberosa, Sarcocephalus latifolius, Terminalia avicennioides, and Zanthoxylum zanthoxyloides.

\subsubsection{Statistical analysis of biomass data}

Data for the different biomass components (tree, shrub, and herbaceous) were compiled for each plot. Total biomass was not calculated because (i) shrub biomass accounts for only leaves and twigs, and thus, including stem biomass would significantly change the contribution of shrubs to the total biomass; (ii) tree biomass was often 3 to 4 orders of magnitude larger than either shrub or herbaceous biomass, and (iii) due to the measurement of the dominant phanerophyte species, shrub, and tree parameters would be underestimated by a few per cent. Average, standard deviation, and standard error were calculated for shrub crown area $\left(\mathrm{m}^{2} \mathrm{ha}^{-1}\right)$, shrub leaf, and twig biomass $\left(\mathrm{t} \mathrm{DM} \mathrm{ha}{ }^{-1}\right)$, tree basal area $\left(\mathrm{m}^{2} \mathrm{ha}^{-1}\right)$, tree biomass ( $\left.\mathrm{t} \mathrm{DM} \mathrm{ha}{ }^{-1}\right)$, and herbaceous biomass $\left(\mathrm{t} \mathrm{DM} \mathrm{ha}{ }^{-1}\right)$ for each land cover class and transhumance zone within the three study regions.

\section{Results}

\subsection{Accuracy assessment and land cover in $\mathbf{2 0 1 7}$}

\subsubsection{Accuracy assessment}

The accuracy assessments for the Ketou, Tchaourou, and Sinende maps yielded an allocation disagreement of $16 \%, 17 \%$, and $13 \%$, respectively; a quantity disagreement of $3 \%, 6 \%$, and $6 \%$, and an overall accuracy of $80.8 \%, 77.6 \%$, and $81.3 \%$. 
Teak (Tectona grandis L. F.) plantations, the most common type of plantation alongside cashew (Anacardium occidentale L.), could not be distinguished from open forest, mainly because this tree species sheds its leaves during the dry season. The same applies for other less important plantation types, like gmelina (Gmelina arborea Roxb.), and oil palm (Elaeis guineensis Jacq.), which were mainly classified as dense shrub.

Grass savannahs could not be distinguished from shrub savannahs at Tchaourou or Sinende, but only at Ketou where they were far more common. Thus, shrub and grass savannahs were combined in one class to ensure a comparison between study regions.

Due to the unavailability of cloud-free images during the cropping period, permanently bare fields were also classified as cropland. Similarly difficult was the detection of fallow fields, which could not accurately be distinguished from cropland and shrub savannah.

\subsubsection{Land cover in 2017}

In 2017, the landscape at the three study regions was dominated by wooded savannah, shrub/grass savannah, and cropland (Appendix D-E). Ground-truthing at the end of the dry season revealed that fire was an important factor in all three study regions (Fig. 3). Sinende exhibited the most signs of recent fires. The high occurrence of recent fires on wooded and shrub savannahs at Sinende and Tchaourou points toward the likelihood of repeated annual fires on these land covers. Croplands were less likely to be burned at these sites. Overall, Ketou exhibited a comparatively reduced incidence of bush fires. ST and WT zones seemed to have a similar fire status.

\subsubsection{Land cover changes from 1986-2017}

The historical land cover maps produced in this study (Appendix E) revealed that land cover changes increased during the second period of observation from 2002 to 2017 (Fig. 4). Cropland grew at all sites, especially during this second time window. This occurred at the expense of shrub/grass savannah at Ketou, woodland savannah at Tchaourou, and both shrub/grass savannah and woodland savannah at Sinende.

At Ketou, the first period (1986-2002) experienced a transformation of shrub savannah to dense shrubland and open forest. The phenomenon could have been stimulated by three consecutive years of high rainfall (218, 373 and $85 \mathrm{~mm}$ above average from 1987 to 1989), although teak and palm plantations established during this period in the northeast corner could be misclassified as open forest. The second period (2002-2017) witnessed an invasion of agriculture throughout the region as cropland replaced shrub savannahs and open forests and plantations replaced open forests and dense shrubland. This resulted in a ubiquitous fragmentation of the overall landscape as pockets of cropland interrupt the flow of common lands and riparian areas began to be farmed. Over the 31-year period, the greatest gain at Ketou was of cropland $(+19 \%)$. About half of the area of community rangelands including ST zones turned from common land to cropland during this period (Fig. 4).

At Tchaourou, much of the wooded areas (dense and open forest/wooded savannah) remained intact from 1986 to 2002. The elliptical-shaped stretch of cropland which transects the study region grew outward into wooded and shrub savannah and became more fragmented, giving evidence of a preference for opening up new land at the peripheries and leaving pockets of fallow land between cultivated fields. The 2002-2017 period contrasts sharply with the previous period, as open forest/wooded savannah was diminished by nearly three-quarters in favour of shrub savannah and cropland. The stretch 
(a)

Open forest/
Wooded savannah
Grass savannah Cropland

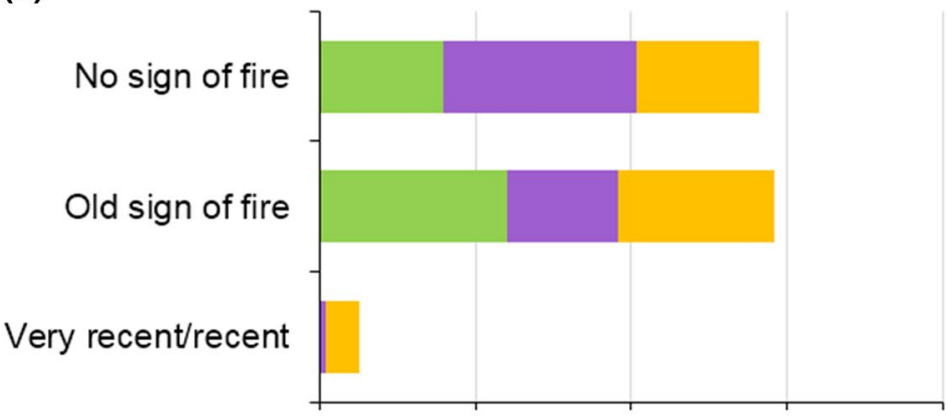

(b)

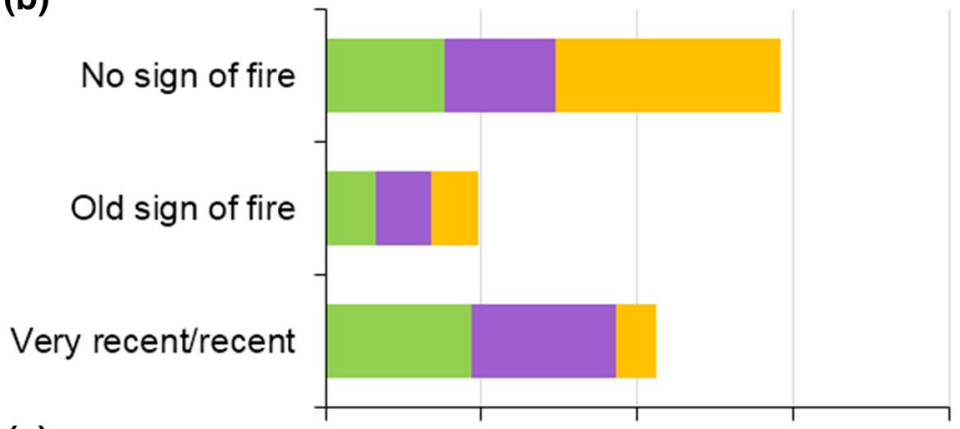

(c)

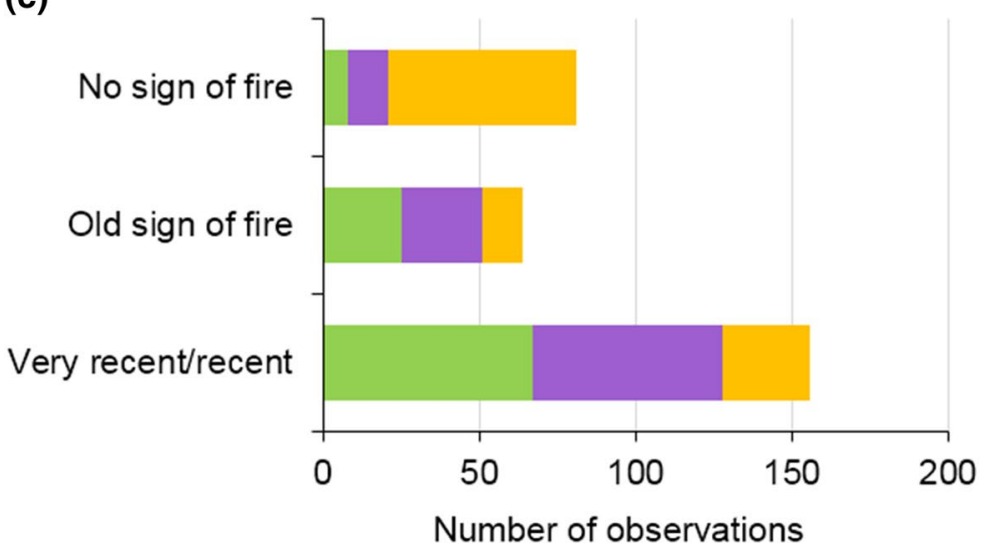

Fig. 3 Fire status observations in 2017 on open forest/wooded savannah, shrub savannah/grass savannah, and cropland (Crop) at a Ketou, b Tchaourou and $\mathbf{c}$ Sinende in Benin

of cropland widened, but pockets of cropland appeared also far into the savannah's interior. Also areas with plantations grew substantially, mainly at the peripheries of cropped areas. Known ST zones in the southwest corner of the region transformed from wood savannah to shrub savannah. Between 1986 and 2017, the greatest gain at Tchaourou 


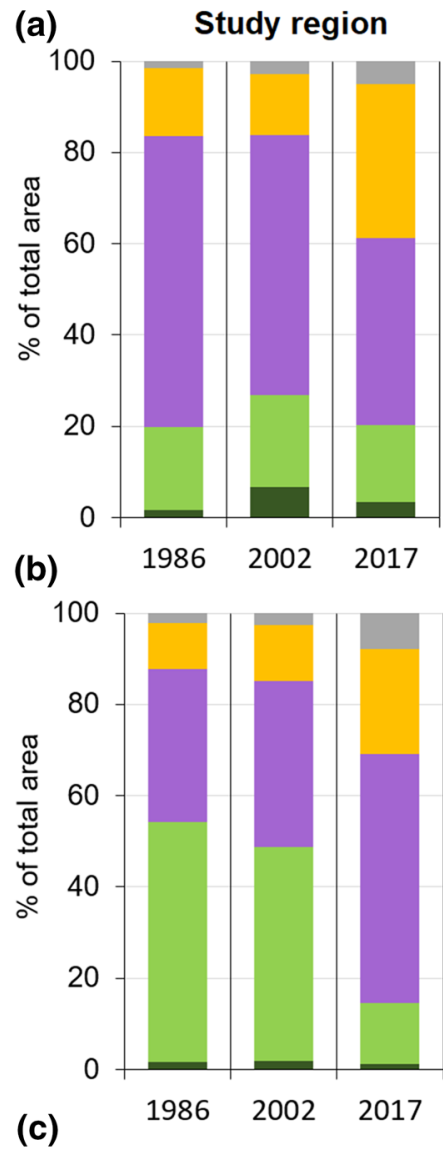

WT zone
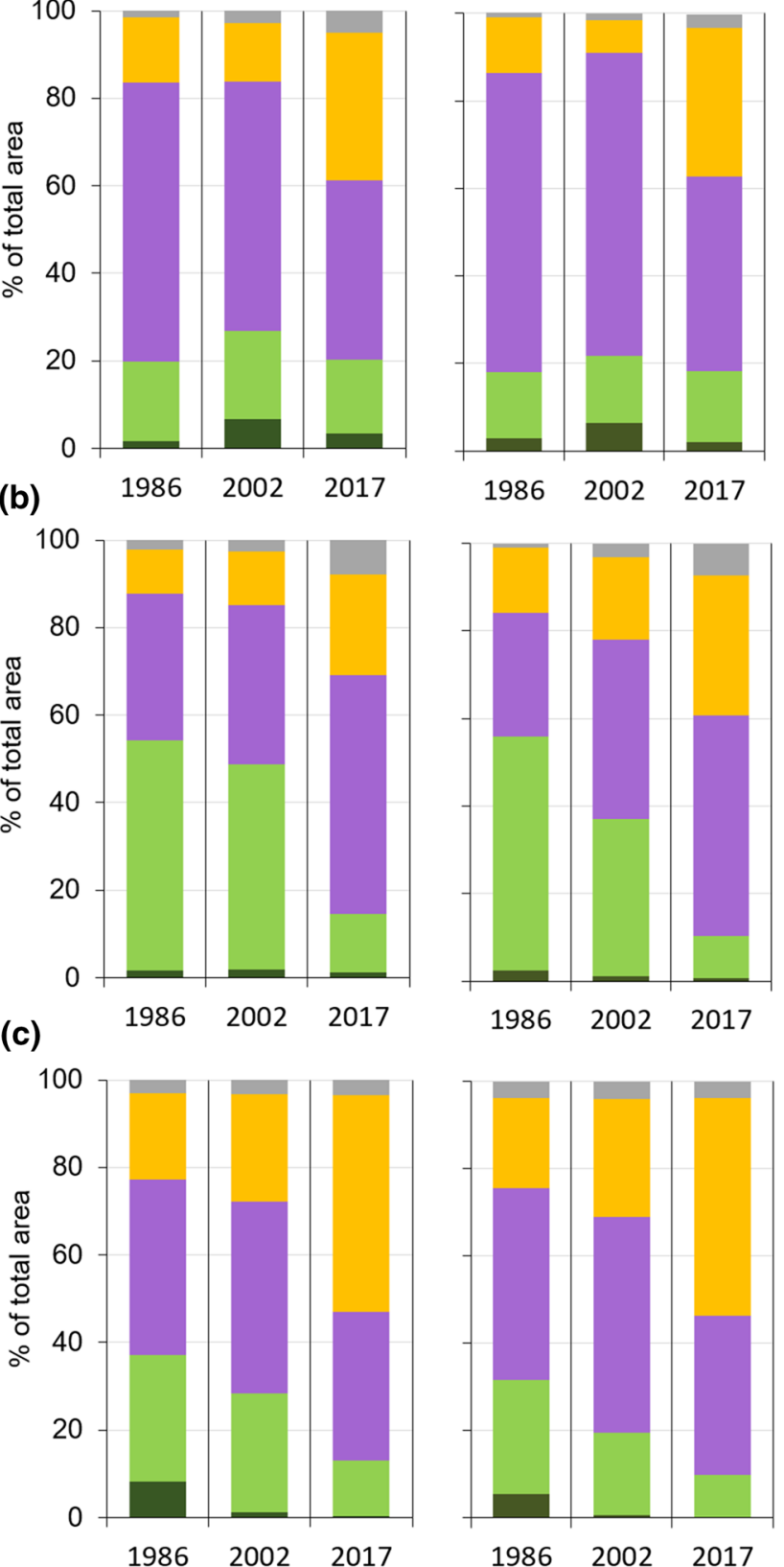

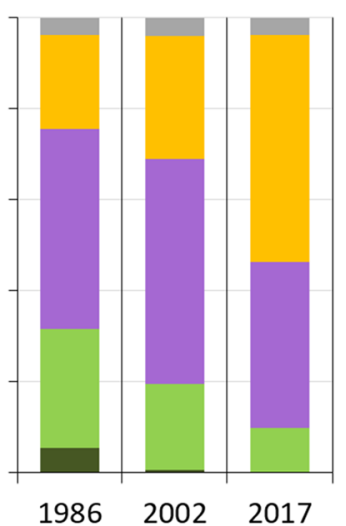

ST zone
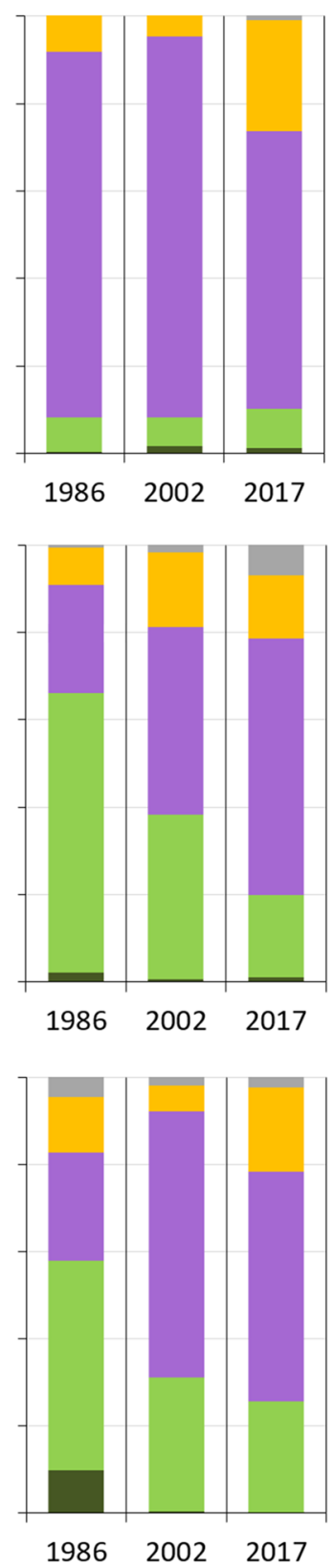

$$
\begin{array}{ll}
\text { Other } & \text { Shrub savannah/Grass savannah } \\
\text { Cropland } & \text { Open forest/ Wooded savannah }
\end{array}
$$

Dense forest

Fig. 4 Per cent of total area by land cover class (other=plantation, built-up, rocky outcrop, surface water) for 1986, 2002 and 2017 for the total study region, WT and ST zones in Ketou (a), Tchaourou (b) and Sinende (b) in Benin 
was of shrub savannah $(+21 \%)$ followed by cropland $(+13 \%)$, while open forest/ wooded savannah experienced the greatest loss $(-39 \%)$.

At Sinende, the starting land cover conditions were relatively fragmented compared with the other sites. During the 1986-2002 period, the cropland belt widened significantly. Closed forests deep inside tracts of open forest/wooded savannah transitioned almost entirely into open forest/wooded savannah, leaving just $1 \mathrm{~km}^{2}$ of the original 38 $\mathrm{km}^{2}$ of closed forest. During the 2002-2017 period, the northern half of the study region experienced widespread cropland expansion, thereby eliminating open forest/wooded savannah from the north. During this period, known ST zones became surrounded by crop fields. In 2017, the landscape got even more fragmented and common lands were highly disconnected. Built-up areas remained small due to the absence of major urban centres. During the 31-year period, cropland had the greatest gain $(+30 \%)$, while open forest took the greatest hit $(-16 \%)$ followed by closed forest $(-8 \%)$.

Among the three sites, the most northern study region, Sinende, experienced the greatest per cent increase in cropland over the 1986-2017 period, while Tchaourou experienced the smallest increase. Deforestation was significant at Tchaourou $(-40 \%)$ and Sinende $(-24 \%)$, but forest cover remained constant at Ketou despite severe fragmentation.

Finally, as hypothesized, conversion to land covers characterized by less relative phytomass was more common than conversion to land covers characterized by more relative phytomass (Table 4). For example, at Ketou, the likelihood that a shrub savannah in 1986 would become a wooded savannah (a land cover of greater phytomass) in 2002 was almost the same as the likelihood that it would become a grass savannah or cropland (land covers of lesser phytomass). However, in the 2002-2017 period, it was 3 times more likely that a shrub savannah would transition to a land cover of less phytomass. During the 1986-2002 period, only the Ketou study region experienced a shift towards increased relative rangeland phytomass. There was a significant difference between the first and second transition periods. For example, during the latter period, 6.2 times as much land area was converted to land covers of relatively less phytomass than to land covers of relatively more phytomass; this strongly contrasts with the corresponding factor (1.3) for the first period.

\subsection{Biomass availability on rangelands in 2017}

At peak vegetation, grasses and forbs offered the greatest quantities of available fodder to livestock among natural vegetation types (Table 5). The highest level of herbaceous biomass was found at Tchaourou, which can be mainly attributed to the differences in sampling time: Tchaourou was sampled at peak vegetation, while the other sites were sampled significantly later.

The data show that herbaceous matter availability is roughly equivalent between wooded and shrub savannahs. Shrub biomass on shrub savannahs was roughly the same at all three sites. While shrub biomass availability was about equal on shrub and wooded savannahs at Tchaourou, it was twice as abundant on shrub savannahs as on wooded savannahs at Sinende. The average lower and upper limits of shrub crowns were 0.94 and $2.45 \mathrm{~m}$, respectively. Tree

Table 4 Ratio of land area converted to land covers of reduced phytomass against land area converted to land covers of greater phytomass in three study regions of Benin

\begin{tabular}{lll}
\hline & 1986 to 2002 & 2002 to 2017 \\
\hline Ketou & 0.9 & 2.4 \\
Tchaourou & 1.3 & 6.2 \\
Sinende & 1.6 & 4.3 \\
\hline
\end{tabular}




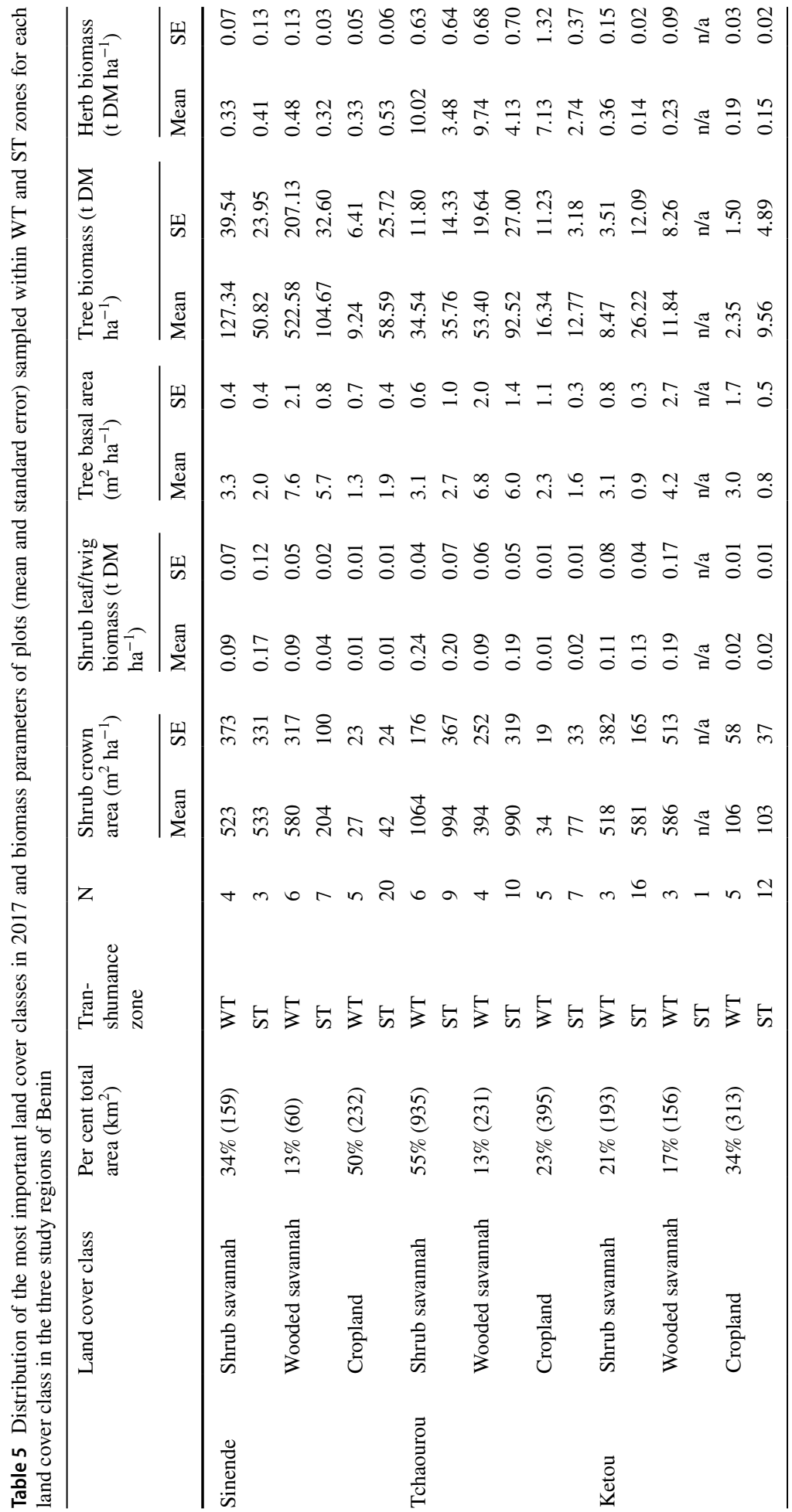


biomass was the highest in Sinende for all land cover classes. Tree biomass was over twice as abundant on wooded savannahs as on shrub savannahs at Sinende and Tchaourou.

As expected, tree and shrub biomass was highest on woodland/ shrub savannahs and lowest on cropland. In fact, shrub biomass was just $1-2 \mathrm{~g} \mathrm{~m}^{-2}$ on all croplands, which is consistent with what was observed in the field on parcels of cropland: farmers commonly do not clear all trees from their cropland, while shrubs are cut annually.

\subsubsection{Effect of transhumance}

At Ketou, ST zones exhibited lower levels of herbaceous biomass on shrub savannahs, whereas at Sinende herbaceous biomass was even higher at ST zones compared to WT zones for shrub savannah. At Tchaourou, far greater quantities were observed in all land cover classes and mean herbaceous biomass on ST zones was far lower than that on WT zones. However, this difference was only significant for shrub savannahs.

No apparent difference related to transhumance intensity was found in shrub biomass or total shrub crown area in the three land cover classes, whereas mean tree biomass was much lower on ST zones for wooded and shrub savannahs at Sinende, while smaller differences were determined at the other study regions (Table 6). For the aggregated data (Table 6), tree biomass on ST zones was on average lower than on WT zones for both wooded and shrub savannahs, and this difference was almost $(p=0.068)$ significant for the latter. Average tree basal area was lower on ST zones in all three land classes, whereby this difference was significant for shrub savannahs according to the Mann-Whitney U-test.

\section{Discussion}

\subsection{Anthropogenic drivers of land cover changes}

Our results indicate that over the last 15 years, it has been far more likely that a unit of rangeland shifted to a land cover of comparatively less biomass than to one of comparatively greater biomass. The observed land cover changes with the transition from open forests/woody savannahs to shrub/grass savannahs and the disappearance of patches of dense forest pointed to a reduction in total phytomass. Between 1986 and 2002, total cropland hardly changed at the three sites, while it doubled (or more than doubled) between 2002 and 2017. The substantial expansion of cropland over the 31-year period in all three study regions is a phenomenon that has been widely cited in studies of land cover change in West Africa (Ayantunde et al., 2014; Brinkmann et al., 2012; Guidigan et al., 2018; Padonou et al., 2017).

Apart from human activities as proximate causes (Lambin \& Geist, 2002) and interacting underlying socio-economic, biophysical and climatic factors (Lambin et al., 2001, 2003), the abovementioned changes in our study regions can be mainly attributed to the following key anthropogenic drivers: (i) population growth and people's need to meet their rising basic requirements; (ii) infrastructural changes and economic development; (iii) cultural factors, and (iv) local peoples' wealth management.

Between 1975 and 2013, Benin's population more than tripled from 3.2 to 10.6 million inhabitants (CILSS, 2016). Such growth is accompanied by the need to satisfy food and energy demands resulting in cropland extension and an increase in fuelwood extraction 
Table 6 Mean, standard error (SE), and $p$ value obtained from the Mann-Whitney U Test for three land cover classes across the three study regions of Benin

\begin{tabular}{|c|c|c|c|c|c|c|}
\hline Land cover & Parameter & Zone & $\mathrm{N}$ & Mean & SE & $p$ value \\
\hline \multirow[t]{10}{*}{ Wooded savannah } & \multirow[t]{2}{*}{ Shrub biomass $\left(\mathrm{t} \mathrm{ha}^{-1}\right)$} & WT & 11 & 0.1 & 0.04 & \multirow[t]{2}{*}{0.611} \\
\hline & & ST & 18 & 0.1 & 0.03 & \\
\hline & \multirow[t]{2}{*}{ Tree biomass $\left(\mathrm{t} \mathrm{ha}^{-1}\right)$} & WT & 9 & 200.6 & 100.77 & \multirow[t]{2}{*}{0.820} \\
\hline & & ST & 18 & 92.1 & 19.79 & \\
\hline & \multirow[t]{2}{*}{ Herb biomass $\left(\mathrm{t} \mathrm{ha}^{-1}\right)$} & WT & 11 & 3.8 & 1.44 & \multirow[t]{2}{*}{0.963} \\
\hline & & ST & 17 & 2.6 & 0.62 & \\
\hline & \multirow[t]{2}{*}{ Shrub crown area $\left(\mathrm{m}^{2} \mathrm{ha}^{-1}\right)$} & WT & 11 & 513.2 & 175.46 & \multirow[t]{2}{*}{0.580} \\
\hline & & ST & 18 & 691.8 & 200.66 & \\
\hline & \multirow[t]{2}{*}{ Tree basal area $\left(\mathrm{m}^{2} \mathrm{ha}^{-1}\right)$} & WT & 9 & 6.5 & 1.22 & \multirow[t]{2}{*}{0.596} \\
\hline & & ST & 18 & 5.5 & 0.86 & \\
\hline \multirow[t]{10}{*}{ Shrub savannah } & \multirow[t]{2}{*}{ Shrub biomass $\left(\mathrm{t} \mathrm{ha}^{-1}\right)$} & WT & 13 & 0.2 & 0.04 & \multirow[t]{2}{*}{0.691} \\
\hline & & ST & 26 & 0.2 & 0.03 & \\
\hline & \multirow[t]{2}{*}{ Tree biomass $\left(\mathrm{t} \mathrm{ha}^{-1}\right)$} & WT & 13 & 57.1 & 18.41 & \multirow[t]{2}{*}{0.068} \\
\hline & & ST & 27 & 31.8 & 8.58 & \\
\hline & \multirow[t]{2}{*}{ Herb biomass $\left(\mathrm{t} \mathrm{ha}^{-1}\right)$} & WT & 13 & 4.8 & 1.42 & \multirow[t]{2}{*}{$0.028 *$} \\
\hline & & ST & 25 & 1.4 & 0.39 & \\
\hline & \multirow[t]{2}{*}{ Shrub crown area $\left(\mathrm{m}^{2} \mathrm{ha}^{-1}\right)$} & WT & 13 & 771.8 & 168.64 & \multirow[t]{2}{*}{0.735} \\
\hline & & ST & 26 & 686.7 & 145.45 & \\
\hline & \multirow[t]{2}{*}{ Tree basal area $\left(\mathrm{m}^{2} \mathrm{ha}^{-1}\right)$} & WT & 13 & 3.2 & 0.34 & \multirow[t]{2}{*}{$0.000^{*}$} \\
\hline & & ST & 27 & 1.5 & 0.37 & \\
\hline \multirow[t]{10}{*}{ Cropland } & \multirow[t]{2}{*}{ Shrub biomass $\left(\mathrm{t} \mathrm{ha}^{-1}\right)$} & WT & 15 & 0.0 & 0.01 & \multirow[t]{2}{*}{0.983} \\
\hline & & ST & 38 & 0.0 & 0.00 & \\
\hline & \multirow[t]{2}{*}{ Tree biomass $\left(\mathrm{t} \mathrm{ha}^{-1}\right)$} & WT & 15 & 9.3 & 4.30 & \multirow[t]{2}{*}{0.294} \\
\hline & & ST & 35 & 34.0 & 13.06 & \\
\hline & \multirow[t]{2}{*}{ Herb biomass $\left(\mathrm{t} \mathrm{ha}^{-1}\right)$} & WT & 14 & 2.7 & 1.01 & \multirow[t]{2}{*}{0.697} \\
\hline & & ST & 36 & 0.8 & 0.16 & \\
\hline & \multirow[t]{2}{*}{ Shrub crown area $\left(\mathrm{m}^{2} \mathrm{ha}^{-1}\right)$} & WT & 15 & 55.5 & 22.26 & 0.933 \\
\hline & & ST & 38 & 67.6 & 17.87 & \\
\hline & Tree basal area $\left(\mathrm{m}^{2} \mathrm{ha}^{-1}\right)$ & WT & 15 & 2.2 & 0.69 & 0.700 \\
\hline & & ST & 35 & 1.5 & 0.25 & \\
\hline
\end{tabular}

$* p<0.05$, indicating the likelihood of a significant difference between LT and GT zones

(Guidigan et al., 2018). Although access to the electrical grid has improved since the 1980s, a majority of rural households still opt for the cheaper fuelwood or charcoal rather than electricity or gas for cooking and light. The growth of the cotton industry in Benin was bolstered by the construction of cotton gin factories in Parakou, leading to agricultural expansion to meet cash crop demands rather than those of food security.

Connection to the road network and accessibility of a specific piece of land are some of the main underlying factors causing LULCC, which was confirmed by many studies, in particular for deforestation (Aguiar et al., 2007; Brinkmann et al., 2012; Nagendra et al., 2003). By facilitating the transportation of cheap charcoal to the urbanized areas in the south, accessibility played a key role in forest losses and fragmentation in our study regions, especially at Sinende between 1986 and 2002. While Sinende was first connected 
by a paved road to the northern city of Parakou in 1992, Parakou and Tchaourou were connected to the southern road network via the renovated Dassa-Parakou highway in 2005.

Cultural factors as another important driver include the existence of unreflective norms and traditions concerning environmental management which persist in society and threaten natural resources, while conservation taboos are weakened. Bush fires have a long tradition in West Africa as they have been used for millennia for hunting but also to check the growth of vegetation on lands used by humans for farming, grazing, and settlement (Hough, 1993). While this study took only a superficial look at bush fires, high frequency of annually recurring bush fires was observed at all study regions.

In areas particularly affected by bush fires, a slow shift from woodier land covers to less woodier ones is likely (e.g. woodland savannah to shrub savannah or shrub savannah to grassland savannah; Sankaran et al., 2008). Such a gradual shift in vegetation structure (and potentially land cover) due to a suppression of woody biomass has been observed in longterm studies on woody savannahs in South Africa (Higgins et al., 2007) and in West Africa (Brookman-Amissah et al., 1980). While the current study cannot conclude links between fires and land cover shifts or biomass levels, the soaring frequency of fire observed at the ground-truthing sites in the 2016-2017 dry season indicates that many lands are burnt so frequently that this suppresses the development of plants with longer life cycles (woody perennials). In contrast to the tradition of bush fires, local conservation taboos still seem to have a protective effect on natural resources. One example is the $3.5-\mathrm{km}^{2}$ high-canopy dense forest located in the centre-north of the Ketou study region (Adakplame forest, see Appendix E), which is protected by local taboos (voodoo) that forbid extraction. The successful preservation of this forest contrasts with that of the classified state "forest" of Ketou located to the west of the Adakplame forest, a $130 \mathrm{~km}^{2}$ area of shrub savannah, of which nearly $1 / 3$ was converted to agriculture by 2017 .

The fourth major driver of the land cover changes exhibited in this study is more complex and comprises wealthy people's desire to productively store personal wealth. This is particularly evident in Ketou where significant agricultural investments (via buying or renting of land) by residents of the coastal urban areas resulted in cropland and plantation expansion during the second period. Sedentary agriculturalists store wealth by accumulating livestock of their own (Moritz et al. 2009), much like transhumant people have done historically. As such, animals increasingly act as insurance against hard times and supply sedentary farmers with a source of regular income from sales of milk, eggs, and other products (Herrero, 2004). This resulted in an increasing pressure on the remaining grazing lands triggering degradation processes accompanied with changes in land cover.

\subsection{Implications of rangeland transformation on forage provision and transhumant pastoralism}

"Natural" rangelands not only diminished in size, but increasingly appeared as agglomerations of multiple land classes or mosaicked landscapes. While large swathes of pure savannah or forest are characteristic of the 1986 images, such large tracts of a single land cover hardly remain 31 years later. This prevailing phenomenon of disconnected rangelands has serious implications for transhumant herders, as they become "trapped," unable to pass through traditional corridors due to the threat of (violent) conflict with farmers. The erosion of traditional transhumant corridors by sedentary people is, thus, not only an infringement of pastoralists' mobility, but also a threat to peace. In 2017, the northern regions of Benin reported a total of 17 deaths resulting from conflicts between sedentary 
and transhumant people. The restricted mobility decreases pastoralist opportunities to optimize weight gain and milk production in the wet season and to limit weight loss in the dry season (Moritz, 2010; Krätli and Schareika 2010).

As the dry season progresses, senescent herbaceous forage must be increasingly supplemented by browse forage. Although diets of cattle generally do not consist of more than $25 \%$ browse (Hiernaux et al. 2004), it comprises a considerable part of bovine nutrition, particularly towards the end of the dry season and the onset of the rainy season (Hiernaux et al. 2004; Schlecht et al., 2006; Ouédraogo-Koné et al., 2006). Most of the dominant species in this study are evergreen, maintaining their foliage even throughout the dry season. However, Menaut and Cesar's (1979) assessment of four dominant woody perennial species in Cote d'Ivoire revealed that for specimens over $8 \mathrm{~m}$ in height (trees), the leaf component of total above-ground biomass was just $1.9 \%$ to $5.6 \%$ on different types of savannahs. Furthermore, most leaves and twigs of trees with a DBH of $10 \mathrm{~cm}$ or greater are at a height out of reach to livestock. Although local and Fulani herders sometimes climb highly valued trees to lop branches, this comprises only a small part of the diet of an average animal.

Nevertheless, the transformation of rangelands towards land covers of lesser biomass (e.g. the shift of shrub savannahs to grass savannahs seen at Ketou) threatens this resource base. This shift is caused by frequent fires, intensified herbivory, and wood extractiondisturbances which all favour less woody land covers over woodier ones.

\subsection{Transhumant pastoralism and forage provision}

The two delineated zones with weak and strong transhumance pressure do not necessarily indicate differences in grazing intensity, and local herds are not excluded from ST zones. However, ST zones are found within transhumant corridors, meaning that they are grazed regularly and by transhumant herds which are generally significantly larger herds than local herds. Nevertheless, our results were not able to depict a clear transhumance effect on rangeland biomass.

Although the Tchaourou herbaceous data reveal the possibility of a marked effect of long-term transhumance on herbaceous biomass availability (Grass and forb biomass on ST zones was half or even less than half of that in WT zones), causality remains unclear. These data, collected between peak vegetation and harvest time, indicate the status of the vegetation prior to the onset of the dry season when herds could have already passed through. Without knowing stocking densities and the time and frequency of visitation of herds, it remains unclear whether lower herbaceous biomass availability was a short-term effect due to grazing in 2016 or a long-term effect of the land's reduced primary productivity, or due to both. Furthermore, during peak of vegetation growth, the transhumance effect is expected to be low. Grazing of transhumant herds from northern countries occurs mainly during dry seasons, when most plants on rangelands are dormant and grazing has little impact on vegetation (Sullivan \& Rohde, 2002). In contrast hereto, local herds also graze during growing periods, when resting would be much more important for the regeneration of the pasture to ensure flowering, seed production, and biomass production (Oba et al., 2000). Many studies conclude that grazing during wet season is more harmful and that resting in the rainy season is fundamental for ensuring pasture productivity in semi-arid rangelands (Müller et al. 2007a; Müller et al., 2007b; Mudongo et al., 2016).

Our results also showed clear effects of transhumance pressure on tree biomass, especially on shrub savannahs. The high grazing as well as browsing intensity on these 
rangelands over decades (or centuries) probably slowed the cycle of tree regeneration. There might also be an overlying effect of bush fires; however, WT and ST zones were subjected to similar fire regimes.

\section{Conclusions}

Major changes in land cover have occurred between 1986 and 2017, although to a greater extent in the latter part of this period (2002-2017) during which the land under agriculture doubled. While processes like cropland expansion are directly related to food security demands of a growing population and low agricultural productivity, transitions from woody to shrub/grass savannahs reflect human-induced degradation such as timber and fuelwood extraction, overgrazing, and bush burning.

Our study did not indicate consistent long-term effects of transhumance on biomass availability and does not support the generalization that pressures by transhumant herds are triggering overgrazing. This also holds true for increasing cattle stocking densities among resident farmers, and the continued grazing of resident herds during the growing season when rangeland vegetation is most sensitive.

Land scarcity and increasing pressures on biomass resources by different users will eventually require an intensification of land use, as is seen in the Kano close-settled zone of neighbouring Nigeria. However, this will not come without strife and struggle (as is happening now between resident and transhumant people) unless land use planning begins to understand and regulate the activities of all land users-especially livestock owners and herders, farmers, hunters, woodcutters, and charcoal makers. Effective policies should foster education and sensitization that addresses norms and traditions that are not helpful for present-day sustainable land management, provide affordable energy alternatives to replace charcoal, and promote personal wealth storage solutions that are relevant and accessible even to peasant farmers and herders.

\section{Appendix A: Timeline of biomass sampling periods in the study area of Benin, West Africa}

See Fig. 5. 


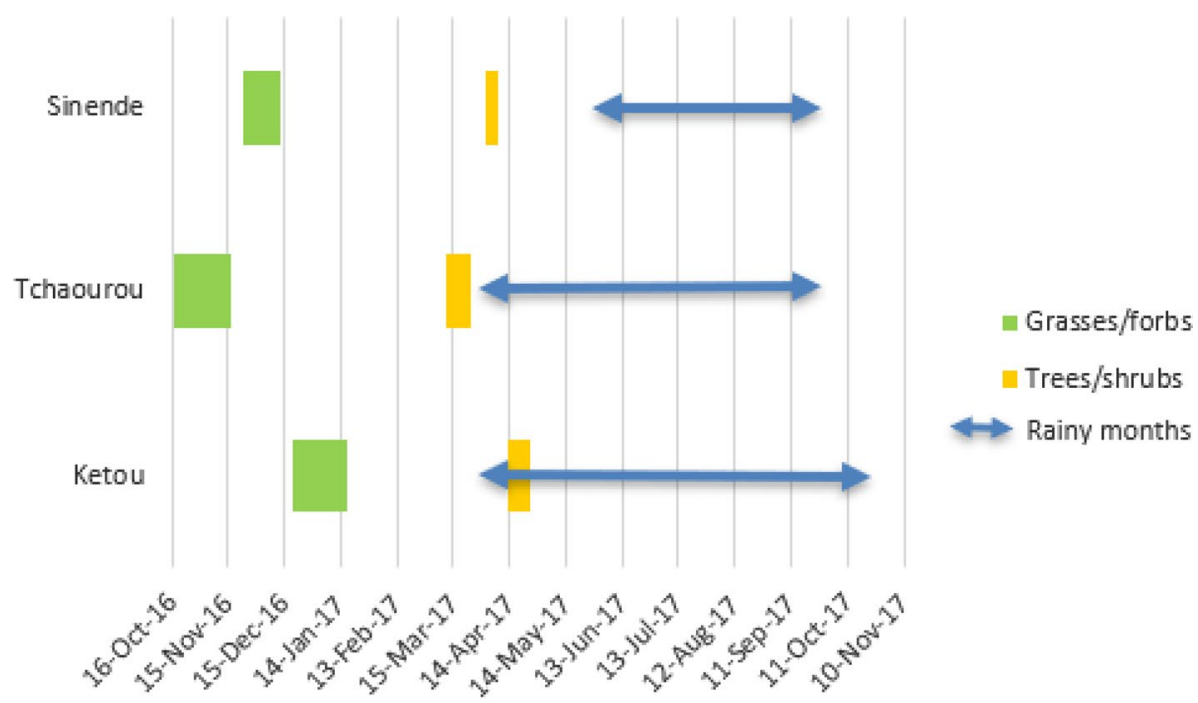

Fig. 5 Periods of biomass sampling in relation to rainy season at the three study regions of Benin

\section{Appendix B: Tree allometric equations and wood density in the study area of Benin, West Africa}

See Tables 7 and 8. 


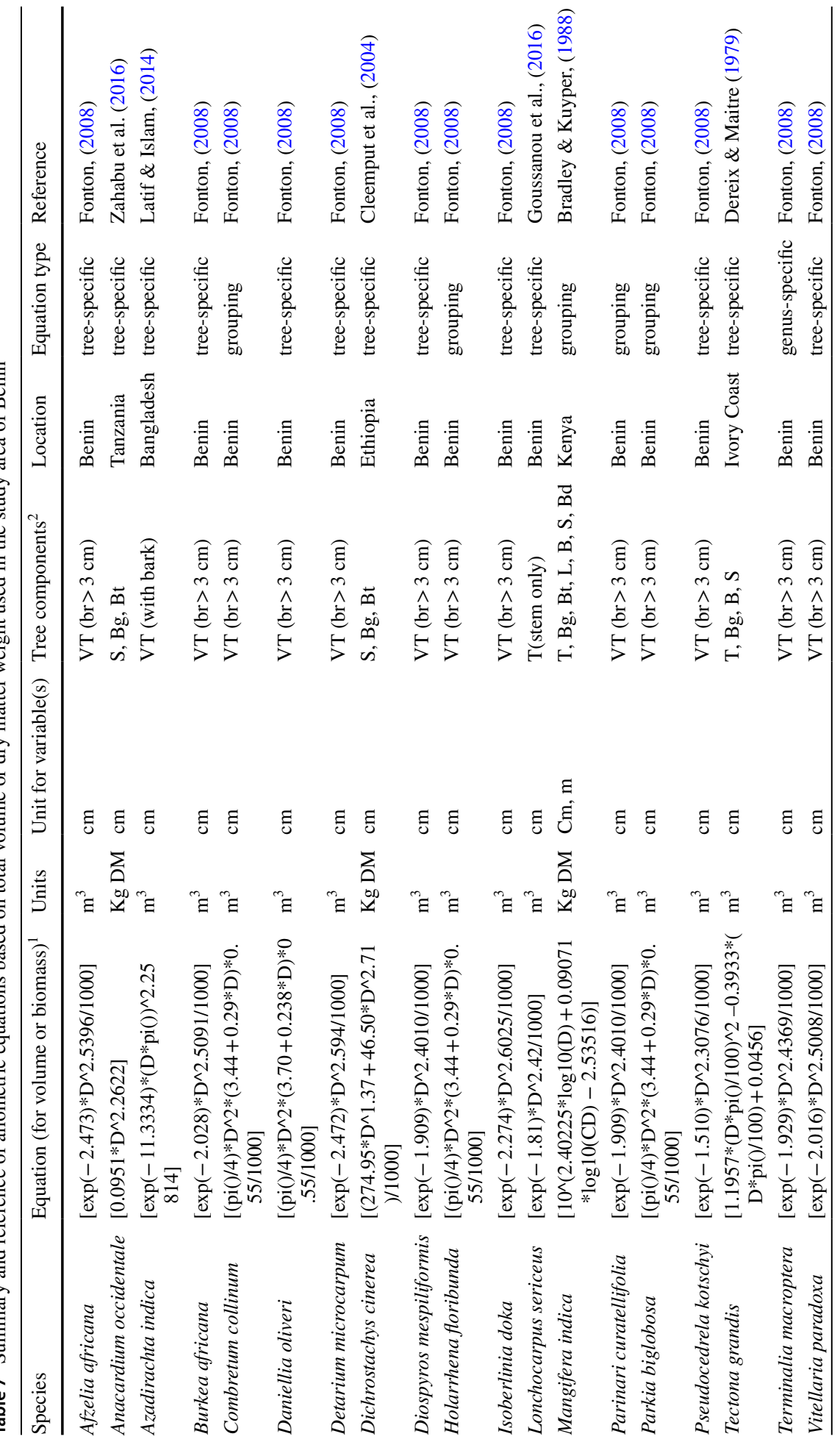




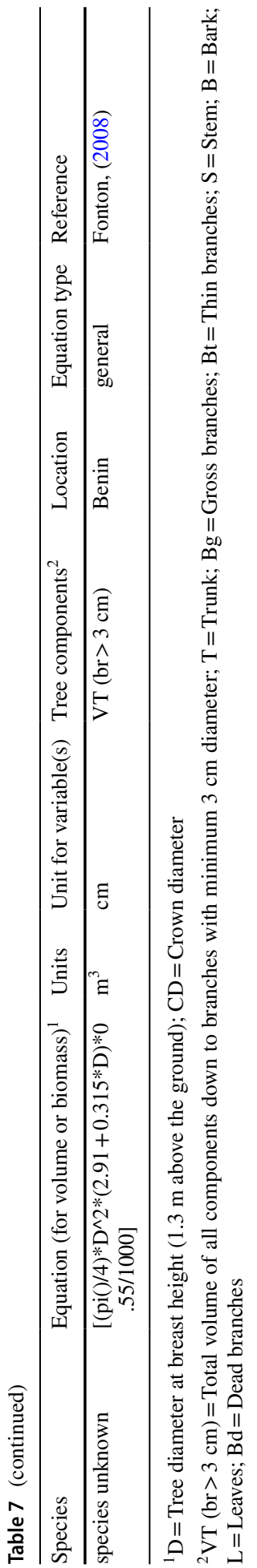

Springer 


\section{Appendix C: General and species-specific shrub biomass prediction models used in the study area of Benin, West Africa}

See Figs. 6, 7, 8 and Table 9.

Table 8 Summary and reference of wood densities used in study area of Benin

\begin{tabular}{|c|c|c|c|}
\hline Species & Density $\left(\mathrm{g} / \mathrm{cm}^{3}\right)$ (average) & Location & Reference \\
\hline Acacia seyal & $0.73-0.80(0.77)$ & unknown & Bolza \& Keating, (1972) \\
\hline Afzelia africana & $0.79-0.82(0.81)$ & Africa & Carsan et al., (2012) \\
\hline Anacardium occidentale & 0.43 & Africa & $\begin{array}{l}\text { Tree Functional Attrib- } \\
\text { utes and Ecological } \\
\text { Database (2017) }\end{array}$ \\
\hline Azadirachta indica & $0.65-0.90(0.78)$ & Africa & Bolza \& Keating, (1972) \\
\hline Burkea africana & 0.80 & Northern Benin & Matilo et al., (2013) \\
\hline Combretum collinum & 0.88 & unknown & $\begin{array}{l}\text { Tree Functional Attrib- } \\
\text { utes and Ecological } \\
\text { Database (2017) }\end{array}$ \\
\hline Daniellia oliveri & $0.58-0.72(0.65)$ & Africa & Bolza \& Keating, (1972) \\
\hline Detarium microcarpum & 0.88 & Northern Benin & Matilo et al., (2013) \\
\hline Diospyros mespiliformis & 0.65 & Northern Benin & Matilo et al., (2013) \\
\hline Holarrhena floribunda & 0.54 & Southern Benin & Goussanou et al., (2016) \\
\hline Hymenocardia acida & 0.63 & Congo & Deklerck, (2015) \\
\hline Isoberlinia doka & 0.57 & Northern Benin & Matilo et al., (2013) \\
\hline Lonchocarpus sericeus & 0.75 & Southern Benin & Goussanou et al., (2016) \\
\hline Mangifera indica & 0.62 & Africa & Carsan et al., (2012) \\
\hline Parinari curatellifolia & 0.46 & Northern Benin & Matilo et al., (2013) \\
\hline Parkia biglobosa & $0.58-0.64(0.61)$ & Africa & Bolza \& Keating, (1972) \\
\hline Pericopsis laxiflora & 0.60 & Northern Benin & Matilo et al., (2013) \\
\hline Pseudocedrela kotschyi & $0.73-0.80(0.77)$ & Africa & Bolza \& Keating, (1972) \\
\hline Tectona grandis & $0.58-0.72(0.65)$ & Africa & Bolza \& Keating, (1972) \\
\hline Terminalia macroptera & $0.81-0.90(0.86)$ & Africa & Bolza \& Keating, (1972) \\
\hline Vitellaria paradoxa & 0.92 & Northern Benin & Matilo et al., (2013) \\
\hline species unknown $^{1}$ & 0.67 & Northern Benin & Matilo et al., (2013) \\
\hline
\end{tabular}

\footnotetext{
${ }^{1}$ Average wood density among the 20 most abundant species in the southern site of the Dahomey Gap woody Savannah study (Matilo et al., 2013)
} 


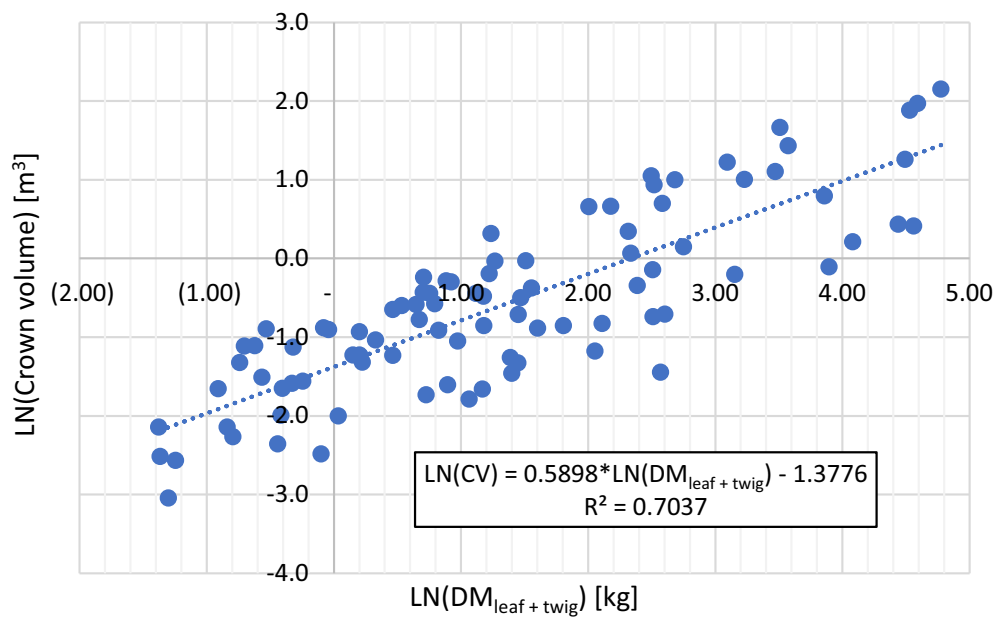

Fig. 6 LN-LN plot of crown volume (CV) against leaf and twig biomass (BM) for 91 shrub samples of 8 species in Benin

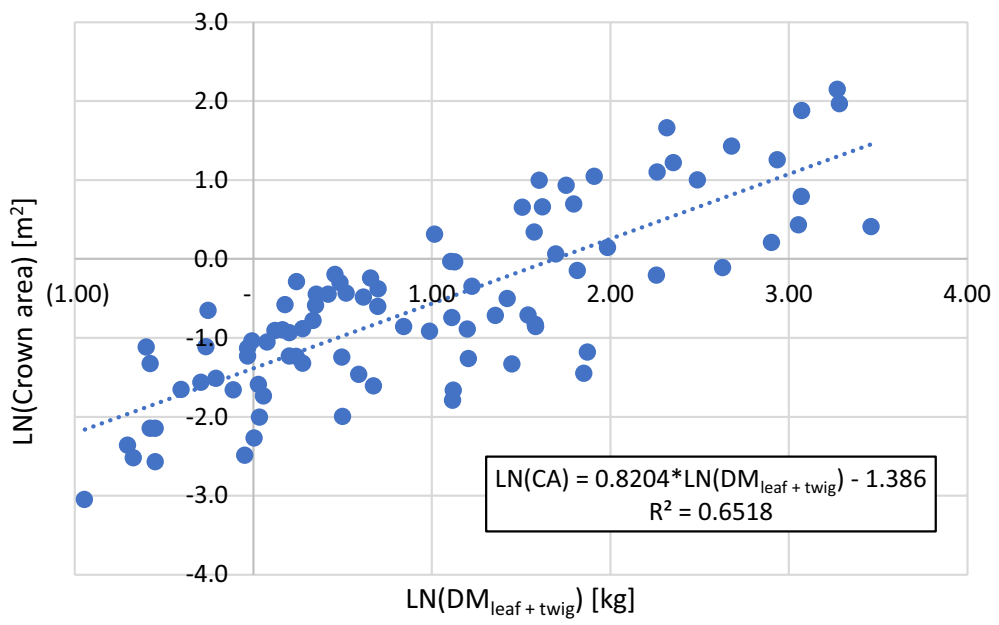

Fig. 7 LN-LN plot of crown area (CA) against leaf and twig biomass (BM) for 91 shrub samples of 8 species in Benin 


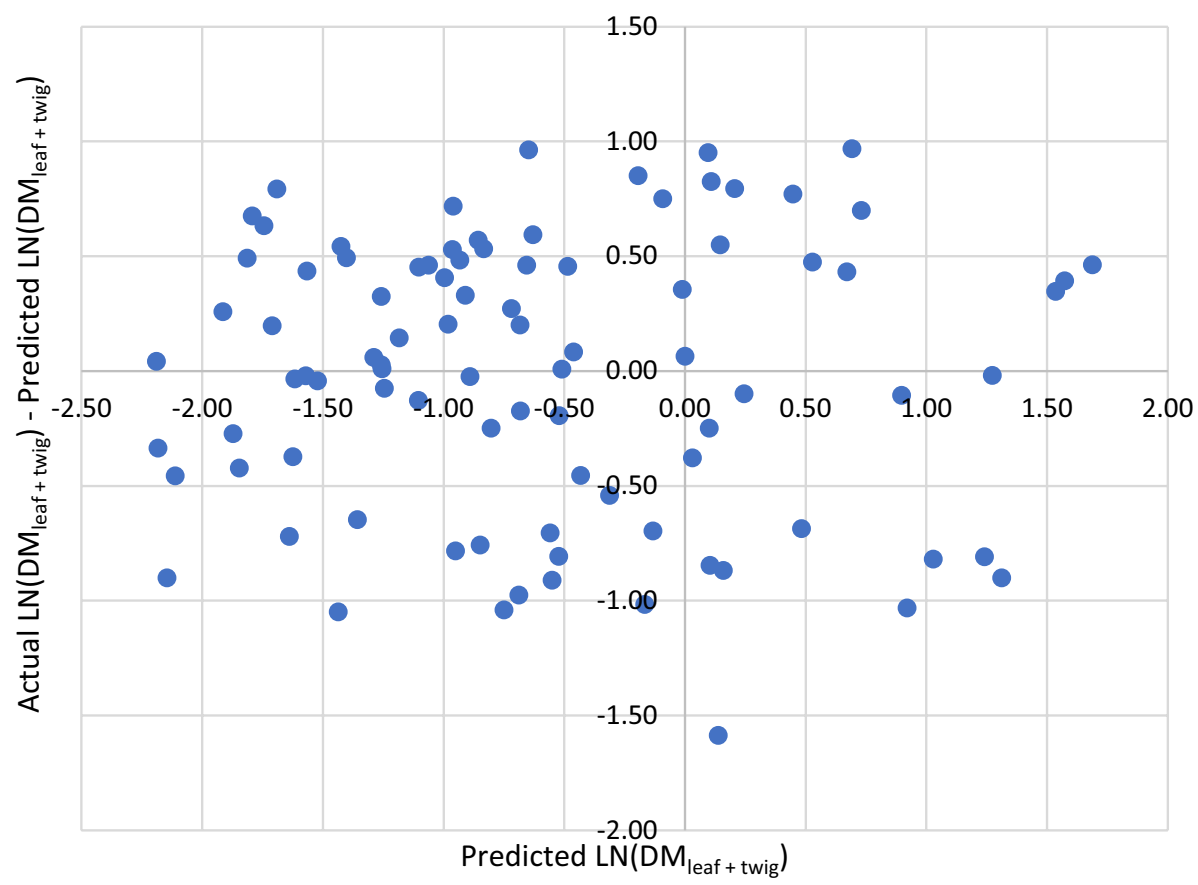

Fig. 8 Residuals for leaf and twig biomass prediction model based on crown volume in Benin

Table 9 Species-specific coefficients for prediction of leaf and twig dry matter $\left(\mathrm{DM}_{\text {leaf }}+\right.$ twig $)$ based on crown volume $(\mathrm{CV})$ according to the model: $\mathrm{LN}\left(\mathrm{DM}_{\text {leaf }+\mathrm{twig}}\right)=\mathrm{a} * \mathrm{LN}(\mathrm{CV})+\mathrm{b}$

\begin{tabular}{|c|c|c|c|c|c|c|c|}
\hline \multirow[t]{2}{*}{ Species } & \multicolumn{3}{|c|}{ Height classes sampled ${ }^{1}$} & \multirow[t]{2}{*}{$\mathrm{N}$} & \multirow[t]{2}{*}{$\mathrm{a}$} & \multirow[t]{2}{*}{$\mathrm{b}$} & \multirow[t]{2}{*}{$\mathrm{R}^{2}$} \\
\hline & Ketou & Tchaourou & Sinende & & & & \\
\hline Annona senegalensis & $\mathrm{A}, \mathrm{B}$ & $\mathrm{C}$ & $\mathrm{A}, \mathrm{B}$ & 13 & 0.677 & -1.882 & 0.642 \\
\hline Flueggia virosa & A,B & & & 6 & 0.717 & -1.263 & 0.936 \\
\hline Gymnosporia senegalensis & $\mathrm{A}, \mathrm{B}$ & & & 6 & 1.180 & -1.403 & 0.976 \\
\hline Piliostigma thonningii & & $\mathrm{A}, \mathrm{B}, \mathrm{C}$ & $\mathrm{A}, \mathrm{B}, \mathrm{C}$ & 21 & 0.543 & -1.044 & 0.754 \\
\hline Pteleopsis suberosa & & $\mathrm{B}$ & $\mathrm{A}, \mathrm{B}, \mathrm{C}$ & 8 & 1.072 & -1.303 & 0.762 \\
\hline Sarcocephalus latifolius & $\mathrm{A}, \mathrm{B}$ & $\mathrm{A}, \mathrm{B}, \mathrm{C}$ & $\mathrm{A}, \mathrm{B}, \mathrm{C}$ & 24 & 0.518 & -0.878 & 0.651 \\
\hline Terminalia avicennioides & & $\mathrm{A}, \mathrm{B}, \mathrm{C}$ & & 10 & 0.695 & -1.699 & 0.840 \\
\hline Zanthoxylum zanthoxyloides & & & & 3 & 0.608 & -1.071 & 0.993 \\
\hline All species & & & & 91 & 0.621 & -1.277 & 0.723 \\
\hline
\end{tabular}

${ }^{1}$ For sites where the species was considered dominant 


\section{Appendix D: Land cover in 2017, 2002 and 1986 in the study area of Benin, West Africa}

See Tables 10, 11 and 12.

Table 10 Distribution of land cover $\left(\mathrm{km}^{2}\right)$ in the three study regions of Benin

\begin{tabular}{|c|c|c|c|c|c|c|c|c|c|}
\hline \multirow{2}{*}{$\begin{array}{l}\text { Total study region } \\
\text { Land cover }\end{array}$} & \multicolumn{3}{|c|}{ Sinende } & \multicolumn{3}{|c|}{ Tchaourou } & \multicolumn{3}{|l|}{ Ketou } \\
\hline & 2017 & 2002 & 1986 & 2017 & 2002 & 1986 & 2017 & 2002 & $1986^{*}$ \\
\hline Closed/gallery forest & 1.0 & 5.3 & 38.5 & 21.1 & 32.6 & 27.8 & 32.3 & 62.3 & 14.4 \\
\hline Plantation & 7.6 & 2.2 & 8.2 & 49.2 & 10.9 & 19.9 & 30.5 & 20.7 & 8.1 \\
\hline Open forest/ Wooded savannah & 59.4 & 127.2 & 135.9 & 230.5 & 803.2 & 901.9 & 162.4 & 187.6 & 168.3 \\
\hline Shrub savannah/ Grass savannah & 159.0 & 206.0 & 187.2 & 930.6 & 626.0 & 576.7 & 311.2 & 498.6 & 567.5 \\
\hline Dense shrubland & 0.0 & 0.0 & 0.0 & 0.0 & 0.0 & 0.0 & 92.6 & 31.8 & 19.5 \\
\hline Cropland & 228.8 & 114.4 & 92.8 & 409.0 & 209.5 & 174.1 & 325.4 & 122.6 & 136.5 \\
\hline Built-up & 5.5 & 11.1 & 4.3 & 15.5 & 16.3 & 4.8 & 14.5 & 4.8 & 4.0 \\
\hline Rock outcrop & 7.0 & 2.0 & 1.5 & 58.8 & 16.3 & 8.2 & 0.0 & 0.0 & 0.0 \\
\hline Surface water & 0.1 & 0.1 & 0.0 & 2.1 & 1.9 & 3.4 & 3.2 & 0.9 & 0.9 \\
\hline Total area $\left(\mathrm{km}^{2}\right)$ & 468 & & & 1717 & & & 929 & & \\
\hline
\end{tabular}

* does not include $10 \mathrm{~km}^{2}$ of cloud cover

Table 11 Distribution of land cover (ha) in the WT zone of the three study regions of Benin

\begin{tabular}{|c|c|c|c|c|c|c|c|c|c|}
\hline \multirow{2}{*}{$\begin{array}{l}\text { WT zone (ha) } \\
\text { Land cover }\end{array}$} & \multicolumn{3}{|c|}{ Sinende } & \multicolumn{3}{|c|}{ Tchaourou } & \multicolumn{3}{|l|}{ Ketou } \\
\hline & 2017 & 2002 & 1986 & 2017 & 2002 & 1986 & 2017 & 2002 & 1986 \\
\hline Closed/gallery forest & 9 & 72 & 651 & 70 & 128 & 264 & 537 & 1432 & 412 \\
\hline Plantation & 209 & 41 & 288 & 371 & 56 & 44 & 448 & 268 & 154 \\
\hline Open forest/ Wooded savannah & 1140 & 2221 & 3057 & 1094 & 4076 & 6081 & 3804 & 3390 & 2915 \\
\hline Shrub savannah/ Grass savannah & 4289 & 5800 & 5140 & 5732 & 4657 & 3203 & 9001 & 14,537 & 14,423 \\
\hline Dense shrubland & 0 & 0 & 0 & 0 & 0 & 0 & 1498 & 747 & 542 \\
\hline Cropland & 5835 & 3155 & 2442 & 3623 & 2134 & 1683 & 7959 & 1644 & 2703 \\
\hline Built-up & 212 & 380 & 110 & 56 & 185 & 16 & 236 & 61 & 39 \\
\hline Rock outcrop & 31 & 55 & 38 & 404 & 115 & 58 & 0 & 0 & 0 \\
\hline Surface water & 0 & 0 & 0 & 1 & 0 & 2 & 56 & 43 & 61 \\
\hline Total area (ha) & \multicolumn{3}{|c|}{11,723} & \multicolumn{3}{|l|}{11,352} & \multicolumn{3}{|l|}{23,539} \\
\hline
\end{tabular}


Table 12 Distribution of land cover (ha) in the ST zone of the three study regions of Benin

\begin{tabular}{|c|c|c|c|c|c|c|c|c|c|}
\hline \multirow{2}{*}{$\begin{array}{l}\text { ST zone (ha) } \\
\text { Land cover }\end{array}$} & \multicolumn{3}{|c|}{ Sinende } & \multicolumn{3}{|c|}{ Tchaourou } & \multicolumn{3}{|c|}{ Ketou } \\
\hline & 2017 & 2002 & 1986 & 2017 & 2002 & 1986 & 2017 & 2002 & 1986 \\
\hline Closed/gallery forest & 0 & 2 & 86 & 16 & 8 & 34 & 22 & 30 & 6 \\
\hline Plantation & 13 & 6 & 36 & 62 & 4 & 7 & 3 & 2 & 5 \\
\hline Open forest/ Wooded savannah & 222 & 268 & 418 & 294 & 587 & 995 & 162 & 118 & 140 \\
\hline Shrub savannah/ Grass savannah & 461 & 534 & 218 & 911 & 668 & 383 & 1100 & 1537 & 1454 \\
\hline Dense shrubland & 0 & 0 & 0 & 0 & 0 & 0 & 51 & 43 & 22 \\
\hline Cropland & 169 & 51 & 112 & 227 & 267 & 134 & 458 & 80 & 138 \\
\hline Built-up & 7 & 11 & 1 & 2 & 14 & 0 & 13 & 2 & 1 \\
\hline Rock outcrop & 1 & 1 & 2 & 42 & 6 & 1 & 0 & 0 & 0 \\
\hline Surface water & 0 & 0 & 0 & 0 & 0 & 1 & 2 & 0 & 0 \\
\hline Total area (ha) & 873 & & & 1555 & & & 1812 & & \\
\hline
\end{tabular}




\section{Appendix E: Land cover maps of the three study region in Benin, West Africa for 2017, 2002, and 1986}

See Figs. 9, 10 and 11.

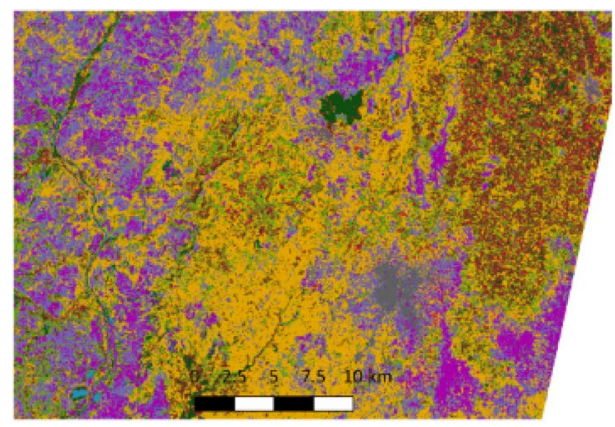

2017
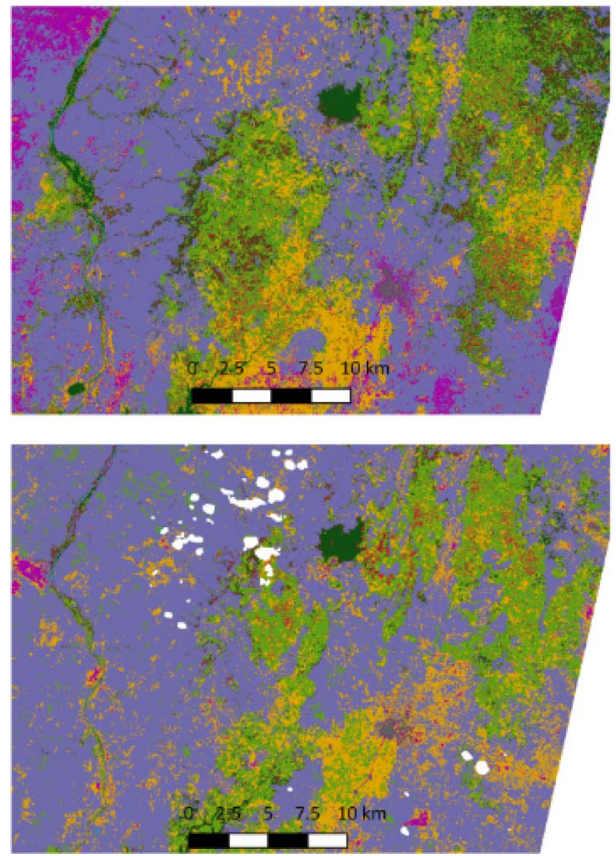

\section{Land cover classes}

Dense Forest

Plantation

Open forest/wooded savannah

Shrub savannah

Grass savannah

Dense shrubland

Cropland

Built-up

Rock outcrop

Surface water

Fig. 9 Land cover at Ketou, Benin, West Africa for 2017, 2002, and 1986 (Note: the eastern bounds of the Ketou study region was reduced for all images based on the limitations of the bounds of the 1986 Landsat 5 image. The reduced size is $943 \mathrm{~km}^{2}$; white areas in the 1986 image are clouds excluded from classification) 


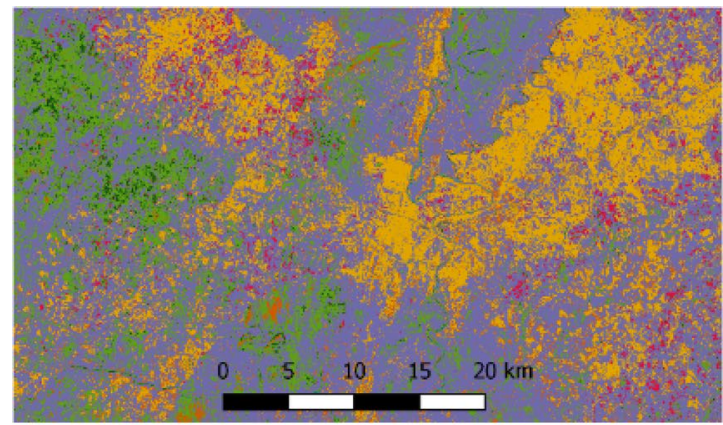

\section{Land cover classes}

Dense Forest

Plantation

Open forest/wooded savannah

Shrub savannah

Grass savannah

Dense shrubland

Cropland

Built-up

Rock outcrop

Surface water

2017

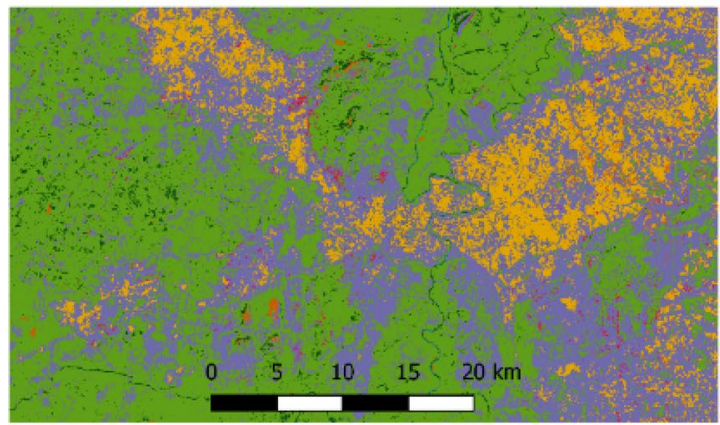

2002

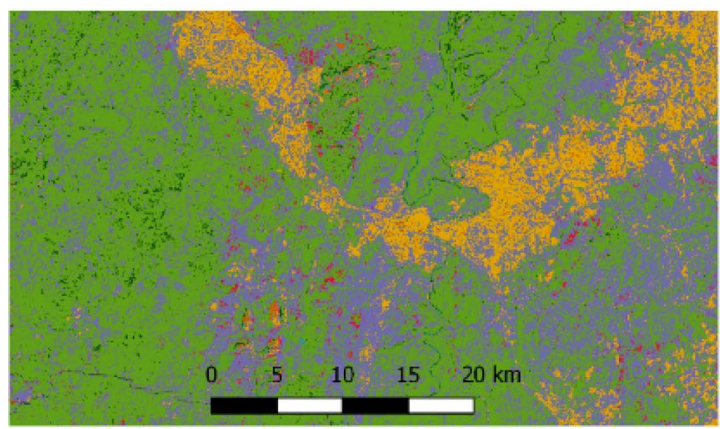

1986

Fig. 10 Land cover at Tchaourou, Benin, West Africa for 2017, 2002, and 1986 


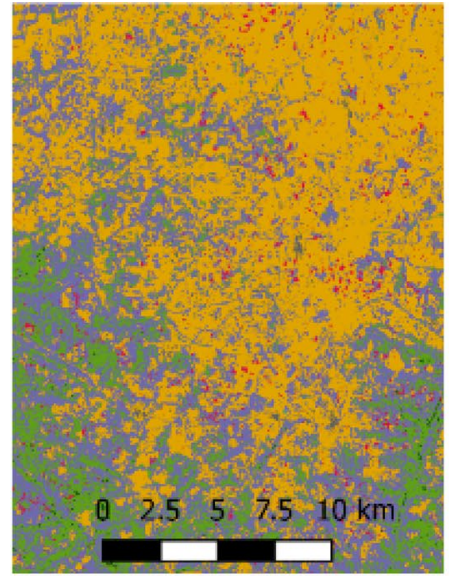

\section{Land cover classes}

Dense Forest

Plantation

Open forest/wooded savannah

Shrub savannah

Grass savannah

Dense shrubland

Cropland

Built-up

Rock outcrop

Surface water
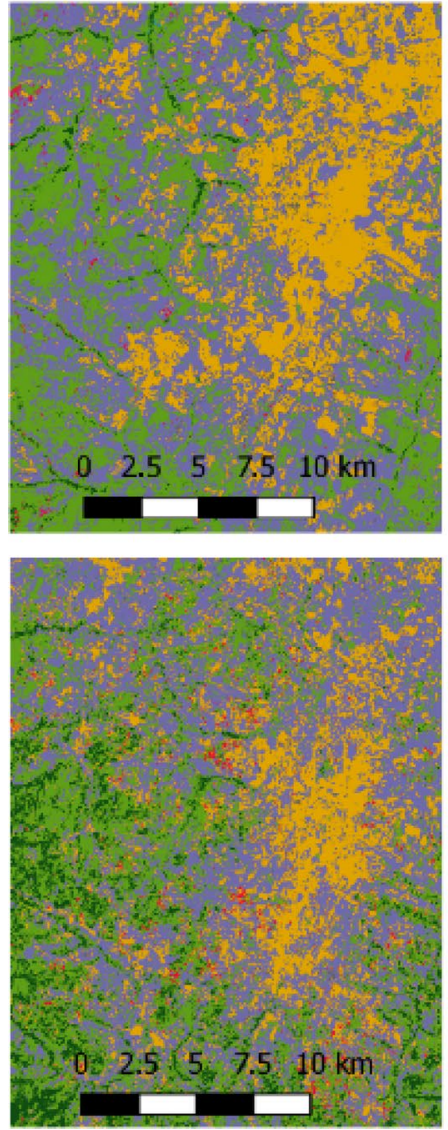

1986

Fig. 11 Land cover at Sinende, Benin, West Africa for 2017, 2002, and 1986 
Acknowledgements The authors wish to acknowledge the VolkswagenStiftung, Hannover (Germany) for funding as well as the team of assistants who worked tirelessly in the field to collect the data, especially Frimence Tossou, Saliou Adedigba, Dimitri Zinvoedo, Augustin Boton, Thomas Hanou, and Benjamin Houeto.

Funding Open Access funding enabled and organized by Projekt DEAL.

Open Access This article is licensed under a Creative Commons Attribution 4.0 International License, which permits use, sharing, adaptation, distribution and reproduction in any medium or format, as long as you give appropriate credit to the original author(s) and the source, provide a link to the Creative Commons licence, and indicate if changes were made. The images or other third party material in this article are included in the article's Creative Commons licence, unless indicated otherwise in a credit line to the material. If material is not included in the article's Creative Commons licence and your intended use is not permitted by statutory regulation or exceeds the permitted use, you will need to obtain permission directly from the copyright holder. To view a copy of this licence, visit http://creativecommons.org/licenses/by/4.0/.

\section{References}

Abbagana, A. L., \& Youla, A. (2009). Gestion des AP et transhumance. La Lettre Des Aires Protégées En Afrique De L'ouest, 17, 6-7.

Aguiar, A. P. D., Câmara, G., \& Escada, M. I. S. (2007). Spatial statistical analysis of land-use determinants in the Brazilian Amazonia: Exploring intra-regional heterogeneity. Ecological Modelling, 209, $169-188$.

Akoègninou, A., Van der Burg, W. J., \& Van der Maesen, L. J. G. (2006). Flore analytique du Bénin. Backhuys Publishers.

AOC (2006). Schéma directeur d'aménagement communal. Commune de Sinende, Departement du Borgou, Republique du Benin. http://www.ancb-benin.org/pdc-sdac-monographies/SDAC/save.pdf (accessed 14 January 2019).

Ayantunde, A. A., Asse, R., Said, M. Y., \& Fall, A. (2014). Transhumant pastoralism, sustainable management of natural resources and endemic ruminant livestock in the sub-humid zone of West Africa. Environment, Development and Sustainability, 16, 1097-1117.

Bassett, T. J., \& Turner, M. D. (2007). Sudden shift or migratory Drift? FulBe herd movements to the Sudano-Guinean region of West Africa. Human Ecology, 35, 33-49.

Baumgärtner, S., \& Quaas, M. F. (2009). Ecological-economic viability as a criterion of strong sustainability under uncertainty. Ecological Economics, 68, 2008-2020.

Benin, S., Ehui, S., \& Pender, J. (2002). Policies for livestock development in the Ethiopian highlands. Socio-economic and Policy Research Working Paper No. 41. The International Livestock Research Institute, Addis Ababa, Ethiopia.

Beyene, F. (2009). Property rights conflict, customary institutions and the state: The case of agro-pastoralists in Mieso district, eastern Ethiopia. The Journal of Modern African Studies, 47, $213-239$.

Bolza, E., Keating, \& W.G., (1972). African timbers-the properties, uses and characteristics of 700 species. African timbers-the properties, uses and characteristics of 700 species. Division of Building Research, Commonwealth Scientific and Industrial Research Organization, Melbourne.

Boutrais, J. (2007). The Fulani and Cattle Breeds: Crossbreeding and Heritage Strategies. Africa, 77, $18-36$.

Bradley, P. N., \& Kuyper, J. B. H. (1988). Woody biomass survey of Kakamega district. Nairobi, Kenya: The Beijer Institute.

Brinkmann, K., Schumacher, J., Dittrich, A., Kadaore, I., \& Buerkert, A. (2012). Analysis of landscape transformation processes in and around four West African cities over the last 50 years. Landscape and Urban Planning, 105, 94-105.

Brookman-Amissah, J., Hall, J. B., Swaine, M. D., \& Attakorah, J. (1980). A re-assessment of a fire protection experiment in north-eastern Ghana savannah. Journal of Applied Ecology, 17, 85-99.

Butt, B. (2010). Pastoral resource access and utilization: Quantifying the spatial and temporal relationships between livestock mobility, density and biomass availability in southern Kenya. Land Degradation and Development, 21, 520-539.

Carsan, S., Orwa, C., Harwood, C., Kindt, R., Stroebel, A., Neufeldt, H., \& Jamnadass, R. (2012). African Wood Density Database. Nairobi: World Agroforestry Centre.

CENATEL-USGS-CILSS (2013). Land Use Changes in Benin. U.S. Geological Survey. https://eros. usgs.gov/westafrica/land-cover/land-use-land-cover-and-trends-benin (assessed 5 March 2017). 
CeRPA (2018a). Evolution de la pluviometrie dans le Borgou. Centre Régional de la Promotion Agricole de Borgou-Alibori (unpublished data).

CeRPA (2018b). Evolution de la pluviometrie dans le Plateau. Centre Régional de la Promotion Agricole de Plateau (unpublished data).

CILSS (2016). Landscapes of West Africa - A Window on a Changing World. U.S. Geological Survey EROS.

Cleemput, S., Muys, B., Kleinn, C., \& Janssens, M. J. (2004). Biomass estimation techniques for enclosures in a semi-arid area: A case study in Northern Ethiopia. University of Göttingen.

Code Pastoral Bénin (2019). Bénin, Code Pastoral Loi n²018-20 du 23 Avril 2019. Droit Afrique Bénin. http://www.droit-afrique.com/uploads/Benin-Code-2019-pastoral.pdf (accessed 10 October 2021).

Congedo, L. (2016). Semi-automatic classification plugin documentation. https://doi.org/10.13140/RG.2.2. 29474.02242/1.

Deklerck, V., 2015. To burn or not to burn: transition from savannah to forest in the 'mise en défens' in Manzonzi (Bas - Congo province in the Democratic Republic of Congo). Doctoral thesis at the Faculty of Bioscience Engineering, World Wildlife Fund Belgium.

Dereix, C., \& Maitre, H. F. (1979). Tarif de cubage du Teck en Côte d'Ivoire. Abidjan: Centre Technique Forestier Tropical.

Decret Ministériel (2019). Modalités de déroulement de la campagne de transhumance 2019-2020 en République du Bénin. https://www.maroobe.com/images/DOCS/Arr\%C3\%AAt\%C3\%A9\%20Tra nshum\%202019-2020_12-11-2019-1547.pdf (accessed 10 October 2021).

Dickhoefer, U., Buerkert, A., Brinkmann, K., \& Schlecht, E. (2010). The role of pasture management for sustainable livestock production in semi-arid subtropical mountain regions. Journal of Arid Environments, 74, 962-972.

Diogo, R.V.C. (2018). Vegetation surveys of trees, shrubs and herbs in Sinende (North), Tchaourou (Centre) and Ketou (South) Benin (unpublished data).

Diogo, R. V. C., Agandan, E. M. M., Nouatin, G. S., \& Djedje, M. (2017). Modes de gestion de la fertilité des sols des agro-éleveurs peuls au Nord-Ouest Bénin: Implications pour la sécurité alimentaire. Annales De L'université De Parakou, Sciences Naturelles Et Agronomie, 1, 74-81.

Diogo, R. V. C., Dossa, L. H., Vanvanhossou, S. F. U., Abdoulaye, B. D., Dosseh, K. H., Houinato, M., Schlecht, E., \& Buerkert, A. (2021). Farmers' and Herders' Perceptions on Rangeland Management in Two Agroecological Zones of Benin. Land, 10(4), 425.

Djohy, G. 2017. Pastoralism and socio-technological transformations in northern benin: fulani innovations in pastoral migration, livelihood diversification and professional association. Göttingen University Press. ISBN: 978-3-86395-346-1

FAO (2012). La transhumance transfrontalière en Afrique de l'Ouest: Proposition de plan d'action. http:// www.interreseaux.org/IMG/pdf/Transhumance_Transfrontalier_en_AO_Rapport_FAO.pdf. (accessed 8 October 2018)

FAO (2018). FAOSTAT Statistical Database. Food and Agriculture Organization of the United Nations. http://www.fao.org/statistics/en/. (accessed 8 October 2018)

Fonton, N.H., (2008). Exécution d'un Inventaire Forestier National (IFN): Méthodologie et résultats de l'élaboration des tarifs de cubage. Projet Bois de Feu - Phase II. Direction des Forêts et des Ressources Naturelles, Ministere de l'Environnement et de la Protection de la Nature, Republique Du Benin.

Gizachew, L. (2012). Drought-induced livestock feed crises and emergency responses. Livestock feed resources in Ethiopia: challenges, opportunities and the need for transformation. Ethiopian animal feeds industry association, Addis Ababa, Ethiopia.

Goussanou, C. A., Guendehou, S., Assogbadjo, A. E., Kaire, M., Sinsin, B., \& Cuni-Sanchez, A. (2016). Specific and generic stem biomass and volume models of tree species in a West African tropical semi-deciduous forest. Silva Fennica, 50, 1474.

Guidigan, M. L. G., Sanou, C. L., Ragatoa, D. S., Fafa, C. O., \& Mishra, V. N. (2018). Assessing land use/land cover dynamic and its impact in Benin Republic using land change model and CCI-LC products. Earth Systems and Environment, 3, 127-137.

Hampshire, K. (2004). Fulani. In C. R. Ember \& M. Ember (Eds.), Encyclopedia of medical anthropology (pp. 656-664). Kluwer. https://doi.org/10.1007/0-387-29905-X_67

Herrero, M., Thornton, P. K., Notenbaert, A. M., Wood, S., Msangi, S., Freeman, H. A., Bossio, D., Dixon, J., Peters, M., van de Steeg, J., Lynam, J., Parthasarathy Rao, P., Macmillan, S., Gerard, B., McDermott, J., Seré, C., \& Rosegrant, M. (2010). Smart investments in sustainable food production: revisiting mixed crop-livestock systems. Science, 327, 822-825.

Hiernaux, P., \& Ayantunde, A. (2004). The Fakara: a semi-arid agro-ecosystem under stress. Report of research activities, first phase (July 2002-June 2004) of the DMP-GEF programme (GEF/271102-4516) ILRI, ICRISAT Centre, Niamey, Niger. 
Higgins, S. I., Bond, W. J., February, E. C., Bronn, A., Euston-Brown, D. I., Enslin, B., Govender, N., Rademan, L., O'Regan, S., Potieter, A. L. F., Scheiter, S., Sowry, R., Trollope, L., \& Trollope, W. S. W. (2007). Effects of four decades of fire manipulation on woody vegetation structure in savannah. Ecology, 88, 1119-1125.

Hobbs, N. T., Galvin, K. A., Stokes, C. J., Lackett, J. M., Ash, A. J., Boone, R. B., Reid, R. S., \& Thornton, P. K. (2008). Fragmentation of rangelands: Implications for humans, animals, and landscapes. Global Environmental Change, 18, 776-785.

Houessou, S. O., Dossa, L. H., Diogo, R. V., Houinato, M., Buerkert, A., \& Schlecht, E. (2019). Change and continuity in traditional cattle farming systems of West African Coast countries: A case study from Benin. Agricultural Systems, 168, 112-122.

Hough, J. L. (1993). Why burn the bush? Social approaches to bush-fire management in West African national parks. Biological Conservation, 65, 23-28.

INSAE (Institut National de la Statistique et de l'Analyse Economique), 2012. Produit intérieur brut. http://www.insae-bj.org/produit-interieur.html (accessed 17 May 2017).

Krätli, S. \& Schareika, N. (2010). Living off uncertainty: the intelligent animal production of dryland pastoralists. European Journal of Development Research, 22, 6.

Lambin, E. F., \& Geist, H. J. (2002). Proximate Causes and Underlying Driving Forces of Tropical Deforestation: Tropical forests are disappearing as the result of many pressures, both local and regional, acting in various combinations in different geographical locations. BioScience, 52, $143-150$

Lambin, E. F., Geist, H. J., \& Lepers, E. (2003). Dynamics of land-use and land-cover change in tropical region. Annual Review of Environment and Resources, 28, 205-241.

Lambin, E. F., Turner, B. L., Geist, H. J., Agbola, S. B., Angelsen, A., Bruce, J. W., Coomes, O. T., Dirzo, R., Fischer, G., Folke, C., et al. (2001). The causes of land-use and land-cover change: Moving beyond the myths. Global Environmental Change, 11, 261-269.

Latif, M.A., Islam, S.Z., 2014. Growth, Yield, Volume and Biomass Equation and Tables for Important Trees in Bangladesh. Forest Inventory Division. Bangladesh Forest Research Institute, Bangladesh.

Lesse, P., Houinato, M. R. B., Djenontin, J., Dossa, H., Yabi, B., Toko, I., Tente, B., \& Sinsin, B. (2015). Transhumance en République du Bénin: états des lieux et contraintes. International Journal of Biological and Chemical Sciences, 9, 2668-2681.

Matilo, A. T. O., Iida, Y., \& Kohyama, T. S. (2013). Tree species composition and stand structure of woody savannah in Dahomey Gap. Tropics, 22, 39-57.

Menaut, J. C. \& Cesar, J. (1979). Structure and Primary Productivty of Lamto Savannas, Ivory Coast. Ecology, 60, 1197-1210.

Moritz, M. (2010). Crop-livestock interactions in agricultural and pastoral systems in West Africa. Agriculture and Human Values, 27, 119-128.

Moritz, M., Kyle, B., Nolan, K.C., Patrick, S., Shaffer, M.F. \& Thampy, G. (2009). Too many people and too few livestock in West Africa? An evaluation of Sandford's thesis. Journal of Development Studies, 45, 1113-1133.

Mudongo, E. I., Fusi, T., Fynn, R. W. S., \& Bonyongo, M. C. (2016). The role of cattle grazing management on perennial grass and woody vegetation cover in semiarid rangelands: Insights from two case studies in the Botswana Kalahari. Rangelands, 38, 285-291.

Müller, B., Frank, K., \& Wissel, C. (2007b). Relevance of rest periods in non-equilibrium rangeland systems - A modelling analysis. Agricultural Systems, 92, 295-317.

Müller, B., Linstädter, A., Frank, K., Bollig, M., \& Wissel, C. (2007a). Learning from local knowledge: Modeling the pastoral-nomadic range management of the Himba, Namibia. Ecological Applications, 17, 1857-1875.

Nagendra, H., Southworth, J., \& Tucker, C. (2003). Accessibility as a determinant of landscape transformation in western Honduras: Linking pattern and process. Landscape Ecology, 18, 141-158.

Oba, G., Stenseth, N. C., \& Lusigi, W. J. (2000). New perspectives on sustainable grazing management in arid zones of Sub-Saharan Africa. BioScience, 50, 35-51.

Ouédraogo-Koné, S., Kaboré-Zoungrana, C. Y., \& Ledin, I. (2006). Behaviour of goats, sheep and cattle on natural pasture in the sub-humid zone of West Africa. Livestock Science, 105, 244-252.

Padonou, E. A., Lykke, A. M., Bachmann, Y., Idohou, R., \& Sinsin, B. (2017). Mapping changes in land use/land cover and prediction of future extension of bowé in Benin, West Africa. Land Use Policy, 69, 85-92.

Pontius, R. G., \& Millones, M. (2011). Death to Kappa: Birth of quantity disagreement and allocation disagreement for accuracy assessment. International Journal of Remote Sensing, 32, 4407-4429.

QGIS Development Team (2018). QGIS Geographic Information System. Open Source Geospatial Foundation. 
Rowntree, K., Duma, M., Kakembo, V., \& Thornes, J. (2004). Debunking the myth of overgrazing and soil erosion. Land Degradation and Soil Development, 15, 203-214.

Sankaran, M., Ratnam, J., \& Hanan, N. (2008). Woody cover in African savannas: The role of resources, fire and herbivory. Global Ecology and Biogeography, 17, 236-245.

Sarwar, M., Khan, M. A., \& Iqbal, Z. (2002). Status paper feed resources for livestock in Pakistan. International Journal of Agricultural Biology, 4, 186-192.

Schlecht, E., Hiernaux, P., Kadaouré, I., Hülsebusch, C., \& Mahler, F. (2006). A spatio-temporal analysis of forage availability and grazing and excretion behaviour of herded and free grazing cattle, sheep and goats in Western Niger. Agriculture, Ecosystems and Environment, 113, 226-242.

Smith, R. J. (2006). Assessing overgrazing in Savannahs. In J. Mistry \& A. Beradi (Eds.), Savannahs and dry Forests: Linking People with Nature. Ashgate Publishing: Aldershot, Burlington, ON, Canada.

Sullivan, S., \& Rohde, R. (2002). On non-equilibrium in arid and semi-arid grazing systems. Journal of Biogeography, 29, 1595-1618.

SWAC/OECD (2007). Promoting and supporting change in transhumant pastoralism in the Sahel and West Africa. Policy Note Number 3, SWAC/OECD, Paris, France.

Tree functional attributes and ecological database, 2017. http://db.worldagroforestry.org//wd (Accessed 07 Jul 2017).

Wang, G. M., Hobbs, N. T., Boone, R. B., Illius, A. W., Gordon, I. J., Gross, J. E., \& Hamlin, K. L. (2006). Spatial and temporal variability modify density dependence in populations of large herbivores. Ecology, 87, 95-102.

Zahabu, E., Mlagalila, H., \& Katani, J.Z., (2016). 11 Allometric biomass and volume models for cashew nut trees. Allometric tree biomass and volume models in Tanzania. E\&D Vision Publishing, Morogoro. Tanzania.

Publisher's Note Springer Nature remains neutral with regard to jurisdictional claims in published maps and institutional affiliations.

\title{
Authors and Affiliations
}

\author{
James Ellison ${ }^{1} \cdot$ Katja Brinkmann ${ }^{1,2} \cdot$ Rodrigue V. Cao Diogo $^{3} \cdot$ Andreas Buerkert $^{1}$ (i) \\ James Ellison \\ jpellison5@gmail.com \\ Katja Brinkmann \\ brinkmann@isoe.de \\ Rodrigue V. Cao Diogo \\ rodrigue.diogo@fa-up.bj
}

1 Organic Plant Production and Agroecosystems Research in the Tropics and Subtropics, Universität Kassel, Steinstrasse 19, 37213 Witzenhausen, Germany

2 ISOE - Institute for Social-Ecological Research, Hamburger Allee 45, 60486 Frankfurt, Germany

3 Département Des Sciences et Techniques de Productions Animale et Halieutique, Faculté d’Agronomie, Université de Parakou, BP 123, Parakou, Republic of Benin 